\title{
MODERN TUNUS ROMANINA BİR BAKIŞ
}

Turgay GÖKGÖZ*

\section{$\ddot{O} z$}

1956 yılında bağımsızlığına kavuşan Tunus, Fransız sömürgesi döneminde uygulanan politikalar nedeniyle edebi bağlamda gelişimini geç tamamlamıştır. Tunus'ta Fransızcadan yapılan edebi çeviriler neticesinde tercüme hareketleri başlamış ve edebi anlamda bir canlanma yaşanmıştır. Zamanla özgün eserler verilmeye çalışılmış ve öykü ile roman türlerinin temelleri atılmıştır. Roman türünde kaleme alınan ilk çalışmaların deneme vaziyetinde olduğu görülürken aynı zamanda hem teknik hem de sanatsal bağlamda zayıf kaldıkları görülmüş̧ür. Buna rağmen bu çalışmalar devam etmiş ve sanatsal anlamda romanın oluşumuna dair bir zemin hazırlanmıştır. Aslında ilk çalışmalar yapılırken Muhammed Hüseyin Heykel'e ait olan ve 1914 yılında Misır'da yayımlanan Zeyneb romanından daha önce Tunus'ta roman türüne dair bir çalışma yapıldığ da gözlenmiştir. Bütün bu gelişmeler yaşanırken Tunus'ta edebi türlerin gelişimine dair en büyük katkının gazeteler ve dergiler tarafından sağlandığı görülmektedir. Söz konusu bu dergiler ve gazeteler üretilen edebi ürünlerin, eleştirilerin ve yazarların tanıtılması hususunda adeta bir meşale olmuşlardır. Söz konusu dergiler ve gazetelerde sadece Tunus'ta ortaya konulan ürünlere yer verilmeyip aynı zamanda Fransız işgaline sahne olan bir diğer ülke Cezayir'de de kaleme alınan çalışmalar ve yazarların hangi konuları işledikleri görülecektir. Söz konusu bu çalışmada tarihi bağlamda roman türünün doğuşu ile gelişimi ve bu gelişim esnasında üretilen edebi ürünler ile romanın ayrıldığ türlere dair detaylı bilgi verilmesi amaçlanmıştır.

Anahtar Kelimeler: Roman, Tunus Edebiyatı, Kuzey Afrika

\section{An Overview of Modern Tunisian Novel}

\section{Abstract}

Tunisia, which became independent in 1956, completed its development very late in the literary context due to policies implemented during the French colonial period. In Tunisia as a result of literary translations made in French, translation movements started and a rebirth literature occured. In the process of time original works were published and the genres of story and novel were laid. While the first novels written in the genre were in experimental condition, they were found to be weak in both technical and artistic contexts. Nevertheless, story and novel proceeded the ground work of artistic basis for the novel was

\footnotetext{
* Dr., Kilis 7 Aralık Üniversitesi, Fen-Edebiyat Fakültesi, Doğu Dilleri ve Edebiyatları Bölümü, Arap Dili ve Edebiyatı Anabilim Dalı, e-posta: turgaygokgoz@kilis.edu.tr Makale Gönderim Tarihi: 21.09.2019

Makale Kabul Tarihi $\quad$ : 10.12.2019

NÜSHA, 2019; (49): 69-96
} 
provided. In fact, throughout the first studies, it was observed that there was a study on the novel genre in Tunisia before the novel of Zaynab, which was published in Egypt in 1914 and belonged to Muhammad Husayn Haykal. While all these developments took place, it was considered that newspapers and magazines made the major contribution to the development of literary genres in Tunisia. These magazines and newspapers elucidated for advertising literary works, critics and authors. In these socalled magazines, not only the products produced in Tunisia, but also the works written in Algeria that witnessed the French invasion and themes they dealts with will be elaborated. In this study, it is aimed to inform the genesis and development of the novel in historical context and the literary products produced during this process and the genres where the novel is separated.

Keywords: Novel, Tunisian Literature, North Africa

\section{Structured Abstract}

In 1881, Tunisia was occupied by the French. This country, which had many censorship and published stages during the French occupation, gained its independence in 1956. Not only Tunisia but also the Maghreb countries, such as Algeria and Morocco, completed their literary development late because of the French occupation and the policies implemented by the colony and the influence of the French language. Therefore, it is seen that the first samples of literary genres such as short stories and novels appeared in these countries later than their counterparts in eastern Arab countries. To determine the authenticity of Tunisian literature, we must first recall that it was subjected to two major influences. First of all, in the literary context, Tunisia is an integral part of Arab literature produced in an area extending from Mauritania in the West to Iraq in the East. The second is an ancient French colony, only 120 kilometers from Italy. For this reason, it was influenced by European ideas both because of geographical proximity and translations from the West.

After the French occupation, Tunisia lived between the years of 19561987, the founding leader of the country Habib Bourguiba. However, political changes did not fundamentally change the content of Tunisian literary texts, and the departure of Bourguiba had almost no influence on Tunisian literature. Therefore, it would be better to look at other instruments other than politics in order to understand the literature of this period. During this period, approximately 680 literary works were published by Tunisian writers, especially from independence to the 1990s, of which 270 were poetry collections and 100 were novels.

The political and social events taking place in the Arab countries were a major obstacle to the reflection of the literary works produced in these countries to other Arab countries. Although writers and literary works in Tunisia are 
under a repressive regime and heavy censorship by the French, it is seen that they have made considerable progress in all genres of literature. However, these studies were carried out through local newspapers for a long time and were confined to narrow borders. In spite of all these negativities, it is obvious that as early as 1905 there were some exits about the genre of story.

In Tunisia, it should be mentioned that Taher al-Haddad (1901/1935), who could be considered as a starting point in the genres of stories and novels, and who could be considered as a pioneer in the issue of the rights of workers and women, carried out in this early period. In terms of the geography of North Africa, many novels have been published since the early years in Tunisia, although the Arab novel did not appear too soon compared to its neighbors. When looking at Arab novelists in Tunisia probably the first of these, Mahmud al-Mas'adî who was professor of Higher Education in France. His expertise in Arabic literature enabled him to gain excellent competence in both Arabic and French cultures. Taha Husayn once mentioned him as follows:

"This Tunisian litterateur has become truly erudite in Arabic
culture and has completed his studies in France, where he has
reached an excellent standard in his knowledge of French
literature. He has been much influenced by the renowned French
philosophical writer Albert Camus".

In any case, al-Mas'adî's novels show a broad culture and intellectual depth. According to some researchers, the definitive beginning of Tunisian novel is based on translations up to the attempts to create original texts. These early essays are not adequate in terms of having the simplest characteristics of artistic Tunisian novels, but they are similar in terms of being short, and discourses are distinguished by the superiority of ideas rather than the characteristics of novel art.

The most vivid use of medium in French colonialism was newspaper articles. At the same time, these intellectual writings, which were used as a weapon against imperialism, had an important role in the development of the prose style in the countries under colonialism. Journalism plays an important role in the publication of novels and short stories in modern Tunisian literature so this situation has continued until just before independence.

Modern Tunisian literature has made significant progress in the literary context after Tunisia's liberation from the French occupation in 1956. Especially as a result of the studies conducted before the independence in general, literature in particular, the novel genre has achieved an artistic momentum. Both this effect and developments in the printing of literary products positively affected the increase in the number of readers and literature. 
Especially after the independence of Tunisia, it is seen that literary works are given at a very serious level and the genre in question is divided into various genres such as national, social and mental novels. According to these genres, various writings were written by the authors, and at the same time, various themes, especially the problems in Tunisian society, were dealt with in various studies and a critical attitude was taken when necessary.

\section{Giriş}

1881 yılında Tunus, Fransızlar tarafından işgal edilmiştir. Fransız işgali süresince pek çok sansüre ve yayım yasağına sahne olan bu ülke, 1956 yılına gelindiğinde bağımsızlığını kazanabilmiştir. Fransız işgali nedeniyle hem sömürgenin uygulamış olduğu politikalar hem de Fransız dilinin etkisi nedeniyle sadece Tunus değil aynı zamanda Cezayir ve Fas gibi Mağrip ülkeleri de edebi gelişimlerini geç tamamlamışlardır. Bu nedenle söz konusu bu ülkelerde özellikle kısa öykü ve roman gibi edebi türlerin ilk numunelerinin doğu Arap ülkelerindeki muadillerinden daha sonra ortaya çıtığı görülmektedir.

Tunus edebiyatının özgünlügünü belirlemek için öncelikle iki büyük etkiye maruz kaldığını hatırlamalıyız. Her şeyden önce, edebi bağlamda Tunus, Batı'da Moritanya'dan Doğu'da Irak'a uzanan bir alanda üretilmiş bir Arap edebiyatının ayrılmaz bir parçasıdır. İkincisi ise, İtalya'dan sadece yüz yirmi kilometrelik uzaklıkta olan eski bir Fransız sömürgesidir. Bu sebeple, hem coğrafi yakınlık hem de Batı'dan yapılan çeviriler nedeniyle Avrupa fikirlerinin etkisi altında kalmıştır ${ }^{1}$.

Fransız işgalinden sonra Tunus, 1956-1987 yılları arasında ülkenin kurucu lideri olan Habib Bûrgîba dönemini yaşamıştır. Ancak politik değişiklikler Tunus edebi metinlerinin içeriğini temelde değiştirmemiş ve Bûrgîba'nın gidişi Tunus edebiyatı üzerinde hemen hemen hiç etkili olmamıştır. Bu nedenle, bu dönemin edebiyatını anlamak için politika dışında diğer etkenlere bakmak daha yerinde olacaktır. Söz konusu bu süre zarfında özellikle bağımsızlıktan 1990’lı yıllara değin Tunuslu edebiyatçılar tarafindan yaklaşık altı yüz seksen edebi eser yayımlandı: bunların iki yüz yetmişi şiir koleksiyonuyken yüzü romandır².

\section{Modern Tunus Romanına Giriş}

Arap ülkelerinde meydana gelen siyasal ve sosyal olaylar, bu ülkelerde üretilen edebi çalışmaların diğer Arap ülkelerine yansımasında büyük bir engel teşkil etmekteydi. Tunus'taki yazarların ve edebî çalışmaların, Fransızlar tarafından uygulanan baskıcı bir rejimin ve ağır bir sansürün altında olmasına rağmen, edebiyatın bütün türlerinde azımsanmayacak derecede ilerlemeler kaydettiği görülmektedir. Ancak bakıldığında bu çalışmalar uzun süre boyunca yerel gazeteler üzerinden gerçekleşerek dar sınırlara hapsolmuştur. Tüm bu olumsuzluklara rağmen, 1905 yılı gibi erken bir zamanda öykü türüne dair bazı 
çıkışların yaşandığı ortadadır. Bu yıllarda daha çok Fransızcadan roman ve hikâye çevirileri yapılmaktaydı. Nitekim "Hayru'd-dîn", "es-Se'âdetu'l'Uzmâ", "es-Sevâb", "et-Tekaddum", "Murşidu'l-Umme" ve "el-Bedr" gibi gazete ve dergilerin fikrî ve edebî çalışmalara oldukça yer vermeleri, roman ve hikâye gibi türlerin tanınmasına zemin hazırlamıştır. Ancak Tunus'ta, özellikle öykü ve roman türlerinde hareket noktası sayılabilecek, işçi ile kadın haklarını konu edinme hususunda da öncü kabul edilebilecek olan Tâhir el-Haddâd'ın (1901/1935) ilk denemelerini bu erken dönemde gerçekleştirdiğini zikretmek gerekir ${ }^{3}$.

Üretilen ilk edebî çalışmalarda kadının kültürel ve sosyal bakımdan geri kalış1 işlendi. Bu ilk örnekler arasında Zeynu'1-'Âbidîn es-Senûsî'nin (19011965) el-Habîbe'si, 'Abdulazîz el-Vuslâtî'nin el-Berî'e'si ve Mustafa Hurayyif'in ${ }^{4}$ Dumû' 'u'l-Kamer'ini görmekteyiz. Ayrıca, Muhammed elBeşrûş'un 1937 yılında çıkarmaya başladığı el-Mehâbis adlı dergi, Tunus'un edebî kalkınmasında önemli bir yere sahiptir. Kimi nedenlerden ötürü yayın hayatına ara verilen bu dergi, 1944 yılına gelindiğinde tekrardan yayımlanmaya başlandi. Muhammed el-Beşrûş̧'a izafeten, Alî ed-Du'âcî (1909-1949), Muhammed Alî el-'Ureybî ve Muhammed el-Mes'adî ${ }^{5}$ gibi önemli isimler bu dergide yer alarak Tunus'un edebî kalkınmasına katkıda bulunmuşlardır. el'Âlemu'l-Edebî'den sonra kurulan ve Mahmûd Beyram (1893-1961), 'Ali edDu'âcî ve Muhammed Alî el-'Ureybî'nin aralarında olduğu Tahte's-Sûr (Kale altı) grubu ve özellikle de Mahmûd el-Mes'adî ekolü daha sonraki zamanlarda örnek olacak çok değerli çalışmalara imza atmışlardır. Aynı şekilde Muhammed el-Mezâlî́ ${ }^{6}$ nin 1955 senesinde çıkarmış olduğu el-Fikr adlı dergi hikâye türünde modern bir başlangıcın yaşandığının habercisiydi. Aslında 1956 senesi Tunus edebiyatında bir dönüm noktas1 olarak görülürken, sonrasında gerçekleşen edebi hareketlilik 1964 yılında Nâdi'l-Kıssa (Hikâye Kulübü)'nın kurulmasıyla da hız kazanmıştır. Bu arada ilmi hayatına 1949 yılında adım atan Tunus'un önemli kültür adamlarından Tâhir Kîka (d.1922) öykü, ‘'̇zzu'd-dîn elMedenî (d.1938) ise hem öykü hem de roman türlerinde başarılı olmuşlardır?.

Tunus romanının doğuşu, araştırmacı Dr. Bûşuş̧e b. Cum'a tarafından iki farklı başlangıca dayandırılmaktadır. Bu başlangıçlardan ilkinde 1930'lu yılların sonu ile 1940'lı yılların başını zaman olarak belirler ki bu dönem, Mahmûd el-Mes 'adî'nin çalışmalarını simgelemektedir. Bahsi geçen çalışmaların ilki 1938 yılında yayımlanan Haddese Ebû Hureyre Kâle ${ }^{8}$ adlı eserdir. Söz konusu bu eser 1973 yllına dek roman şeklinde tam bir metin halinde yayımlanmamıştır'. İlgili bu romanın kahramanı olan Ebû Hureyre, monoton bir hayat yaşamaktadır. Günlerden bir gün bilinci yerine geldiğinde arkadaşı onu bilindik hapis uzamından alıp esrarın ve gizin dünyasına götürmektedir. Bu dünya ki karakter, çölde gözün alabildiğince uzanan ufukları, 
beyaz kumlarda bir kadının ve bir erkeğin dans ettiği bir kare ve ziyafet görmektedir. Ebû Hureyre söz konusu bu ilk hayatına nasıl veda edecek ve varlığın yolculuğuna nasıl çıkacak? soruları merak uyandırmaktadır ${ }^{10}$.

Müellifin bir diğer romanı ise Mevlidu'n-Nisyân adını taşımaktadır. 1945 yılının Nisan ayından temmuz ayına dek fasıllar halinde yayımlanmıştır. 1974 yılında ise kitap halinde basılmıştır.

İkinci bir görüş ise araştırmacı Sâlih ez-Zeker'e ait olan görüştür. Kendisine göre Tunus romanının başlangıcı 1960'lı yılların sonlarına dayanmaktadır. Modern Tunus romanının babası olarak addedilen el-Beşir Hurreyif'e ait olan ed-Dıkla fi 'Aracîniha (1969) adlı roman bu başlangıcın ilk çalışmasıdır. Yukarıda zikredilen tarihlerden önce aşağıda verilen başka çalışmaların da kaleme alındı ğını belirtmek gerekmektedir:

- el-Hayfầ ve Sirâcu'l-Leyl (1906) - Sâlih es-Suveysî el-Kayravânî

- es-Sâhiretu't-Tûnisî - Muhammed es-Sâdık er-Razûkî (1874-1939)

- Necât (1933) - Muhammed Rezzak

Ancak söz konusu bu denemelerin vaaz yapısında olduğu görülmektedir. Yazarları ise edebiyatçılardan ziyade toplumsal reformistlerdir. Söz konusu bu denemelerin sanatsal bağlamda eksiklikleri bulunmaktadır ${ }^{11}$. Bütün bu görüşlerin dışında kimi kaynaklarda 'Ali ed-Du'âcî'ye ait olan Fî Cevle Beyne Hânâti'l-Bahri'l-Esved (1935) adlı çalışma ilk roman olarak zikredilmektedir $^{12}$.

Kuzey Afrika coğrafyasına bakıldığında Tunus'ta Arap romanı komşularıyla kıyaslandığında çok erken ortaya çıkmamış olsa da ilk yıllarından itibaren birçok roman basılmıştır. "Muhtemelen Tunus'taki Arap romancılara bakıldı̆̆ında bunların ilki, Fransa'da yükseköğrenimini alan Prof. Mahmûd elMes 'adî (d.1911) idi. Arap edebiyatındaki uzmanlı̆̆, hem Arap hem de Fransız kültürlerinde mükemmel bir yetkinlik kazanmasını sağladı. Taha Hüseyin bir keresinde ondan şu şekilde bahsetmiştir":

"Bu Tunuslu edebiyatçı Arap kültürüne dair gerçekten de çok bilgindir ve Fransız edebiyatı konusundaki çalışmalarını da bilgisinin mükemmel bir standarda ulaştı̆̆ Fransa'da tamamlamıștır. Nitekim el-Mes 'adî, ünlü Fransız filozof Albert Camus'dan çok etkilenmiştir". ${ }^{13}$

Taha Hüseyin'in bu sözleri kendisinin el-Mes 'adî'nin ilk kez 1955 yılında yayımlanan es-Sudd adlı tiyatro oyununa yönelik eleştiri yazısında yayımlanmıştır ve oyunla ilgili olarak şu şekilde bir tasvire yer vermiştir: " $B u$ tiyatro oyunu - veya daha çok tiyatral öykü denilebilir - çok iyi bilinen bir yazar olan el-Mes'adî tarafindan sergilenmek için değil edebi bir yazı olarak okunması için kaleme alınmıştır" ${ }^{\prime 14}$. Çalışmaya bakıldığında aslında öykünün 
barajın yıkılışıyla birlikte sona ermesi, eserin kaleme alındığı dönemdeki elMes'adî neslinin hayal kırıklığını ifade eden bir metafordur. el-Mes'adî 1976 yılında katıldığ 1 bir konferansta $e s-S u d d$ 'da geçen İslami semboller üzerinde durmuş ve bir önceki gerek Tunuslu gerekse de Arap neslin anti modernist tavırlarına dair yorumlarda bulunmuştur ${ }^{15}$.

Mahmûd el-Mes'adî'nin üslubuna bakıldığında ise "Yazılarında klasik dili kullanır. Mükemmel eski nesir geleneğinin özlü anlatımından, kurall gramatik yapısından, zengin ve çok seçenekli kelime varlı̆̆ından yararlanır. Bu nedenle $R$. C. Ostle'nin dediği üzere edebi Arapçanın pek çok sinırlılıkları, eskilikleri ve eksiklikleri onun elinde edebi bir çalışmanın modernliği ve mesajın ilgisini göz ardl etmeyen yaratıcı araçlarına dönüşmüştür" ${ }^{\prime \prime}$.

Her ne olursa olsun el-Mes'adî’nin romanlarında geniş bir kültür ve entelektüel bir derinlik görülmektedir. Bununla birlikte özellikle de Haddese Ebû Hureyre Kâle adlı eserinde olduğu üzere Klasik Arap belagatından etkilenmiştir, süslü ve detaycıdır. Bu tarz, bazı eleştirmenler tarafından klasik dilin ustalıkla yönünü belirleyen başarılı bir uyarlama olarak görülmüştür. Ancak Hamdi Sakkut'a göre modern ve geleneksel kurguya uygun olarak görülmemiştir. 1974 yılında basılmış olan Mevlidu'n-Nisyân adlı romanından bir pasaj, bu tarzı örneklemeye yardımcı olacaktır. Bu alıntıda, Medyan ve Leyla karakterlerinden ikisi yaşam ve ölümü tartışmaktadır:

Medyan: Zaman parçalarına ayrılmış olmalı ya da tekerlekleri çarpıklaşmış olabilir. İşte bu yüzden zamanın kafası karmakarışık olacak. Zaman ayyaş, sersem insanlar gibi abuk sabuk konuşacak.

Leyla: Sen bir şeyi unutuyorsun. Zaman ulvi bir yoldur. Zaman Allah'in yoludur. Var oluşun yoludur. Zaman ölümün yoludur. Hatta ölüm gizliden gizliye planlarını yapar.

Medyan: Zaman aldatmanın yoludur. Ölümün yoludur. Ben ölümden tiksiniyorum. Çünkü ölüm bence hirsizllktır. Hatta ölüm düzenbazlık, hiledir. Ufuktaki gezegene bakıyorum da ışığını geriden yansittyor mu? Sen hala gezegenin yaşadı̆̆ına inaniyor musun? Yoksa yok olup toz mu oldu. Yoksa gezegen gökyüzünün her bir kössesine parçaları mı saçıldı. Sanki o gezegen hareket ediyormuş gibi yapsa da bence hala gezegenin ışığın algıllyoruz. Fakat muhtemelen çok çok uzun yillar önce o gezegen yok oldu. Ortadan kayboldu. Varlığını sonlandirdı. Gezegen gözden yavaş yavaş kaybolsa da geriye sadece ışı̆̆ kald ${ }^{17}$. 
Böyle bir tarz, okuyucuya kelime bilgisi, cümlelerinin yapısı, eş anlamlıları, tekrarı ve süslemesi anlamında temel olarak entelektüel, soyut ve kavramsallaştırılmış düşünceler sunar. $\mathrm{Bu}$ nedenle, bugünün iyi anlatı kurgusundaki yerleşmiş sanatsal tarzdan uzaktır. Neyse ki, genel olarak Tunuslu romancılar bu demode tarzı kullanmamaktalar. Onlar günümüzde çarpıcı açıklamalarla dolu, canlı olaylar ve renkli karakterlerin yer aldığı basit ve açık bir nesir tarzı geliştirdiler. Bununla birlikte, son yıllarda ortaya çıkan romanların çoğu, yapıdaki bazı temel kusurlardan, inandırıcı ve ikna edici bir anlatı akışı eksikliğinden mustariptir. Nitekim Beşîr b. Selâme'nin ${ }^{18} 1982$ yılında yayımlanan 'Â' 'işe adlı romanı bu dönemin tipik bir örneğidir. Bu roman et-Tâhir karakterinden başlayarak 'A 'işe adlı karakterin doğumuna dek uzanan anlatımsal bir çizgi taşımaktadır ve devam etmektedir. Bu karakterin yaşam öyküsünde XIX. yüzyılın sonlarından 1930'lara kadarki tarihi merhaleler bir araya getirilmektedir. Bir başka önemli roman ise Muhammed el-'Arûsî elMatvî' ${ }^{19}$ 'ye ait olan ve Tunus'ta popülerleşen el-Tûtu'l-Mur, 1967 yıllnda yayımlanmıştır. Bu roman başarısını bir köy halkının gelenekleri, görenekleri ve yaşam tarzına dair gerçekçi tasvirinden almaktadır. Ancak yazar karakterlerini beraberinde getirdiği ahlaki karmaşıklıklara sahip sıradan insanlar olarak değil, ahlaki olarak olması gereken özelliklere sahip karakterler olarak yansıtsa da genellikle bu karakterler ahlaki değillerdir ${ }^{20}$.

Sâlih Suveysî el-Kayravânî’nin Tunus roman sanatının mucidi olduğu hususunda muhtelif kaynaklar hem fikirdirler ve kendisi bu alanın öncüsü durumunda olan bir isimdir. Aslında geleneksel bir şair olarak bilinmektedir. Sonrasında modern şairlerin yolundan gitmiştir. Nesir türüne geçmiş ve Mencemu't-Tebr fi'n-Nesr ve's-Şi $r$ adlı kitabında da olduğu gibi makale ve kısa makame türlerinde yazılar kaleme almaya başlamıştır. Ayrıca 1906 yılında yayımlanan Hayre 'd-dîn Dergisi'nde el-Hayfâ ve Sirâcu'l-Leyl adını taşıyan ilk roman denemesi de mevcuttur ve mukaddimede bu çalışmanın Tunus'ta telif edilen ilk roman olduğunu ifade etmiş bu nedenle de okuyucunun kendisini mazur görmesini istemiş̧ir. Aynı çalışma, 1921 yılında el-Kayravân gazetesinde de yayımlanmıştır ${ }^{21}$. Bu roman, basit bir kısa öykü yapısında olan bir makame olmasının yanı sıra dokusu zayıf olsa da gerçekten önemli bir yere sahiptir. Konusu Cemaleddin el-Afgânî ve Muhammed Abduhu gibi âlimlerin yolundan giden Islahat nesline çağrıda bulunan doğru bir İslami terbiyedir. Romandaki olaylar İslami hareketin bayağı yoğun olduğu bir dönemde geçmektedir. Eserin ana karakteri Sirâcu'l-Leyl, babasının vefatından sonra Islahat hareketlerine dair haberleri takip eden annesi el-Hayfâ' tarafindan özenle büyütülmüştür. el-Hayfâ' ümmetin durumundan haberdar olarak yetişmesine önem verdiği Sirâcu'l-Leyl'i daha sonra Mısır'a dini ve dünyevi ilimleri öğrenmesi için göndermek istemiştir ${ }^{22}$.

Kimi araştırmacıların görüşlerine göre Tunus romanının kesin olarak başlangıcı, özgün metinlerin oluşabilmesi için yapılan tercümelere 
dayanmaktadır. Bu tercümelerin yanı sıra Arapça yapılan ilk denemeler sanatsal Tunus romanın en basit unsurlarına haiz olma açısından yeterli olmayıp aynı zamanda kısa olması açısından da birbirleriyle benzerlik taşır ve söylemlerinde roman sanatının özelliklerinden ziyade düşüncelerin üstünlüğü fark edilir. Üstelik eğitici, reformist ve vaazcı yapıdaki eğilimlerin önceki pek çok bağlamda yer aldığı görülürken sanatsal bir yaklaşımdan ziyade doğrudan açık seçik bir anlatım olduğu görülmektedir ${ }^{23}$.

1930'lu yıllarda Tunus edebiyatında kısa öykü kültürel kesimde seçkin bir kitleye ulaşırken roman okuyucuları ise bu dönemde nicel olarak zayıf durumdaydı. Bu durum 'Ali ed-Dû'âcî ve Mahmûd el-Mes'adî gibi Tunus edebiyatının en önemli kalemlerinin iki dünya savaşı arasındaki süreçte yazmış oldukları ile bağımsızlık sonrasında yazılanlar arasındaki sekteyi apaçık ortaya koyan unsurdur. Daha sonraki dönemde gelecek olan el-Beşîr Hurayyif, Muhammed el-'Arûsî el-Matvî, Muhammed Reşâd el-Hamzâvîni ${ }^{44}$, Mustafâ elFârisî, 'Abdulmecîd 'Atiyye ve Muhammed Sâlih el-Câbirîn ${ }^{25}$ gibi isimler Tunus edebiyatının roman türündeki önde gelen yazarları arasındadır. Zira bu isimlerden bazılarının çalışmaları - örneğin el-Beşîr Hurayyif'in ed-Dıkla fî 'Arâcinihâ adlı romanı gibi - bugünün klasikleri arasında yerini almaktadır'

Tunus'ta roman türünün ilk örnekleri 1930 ve 1940 'lı yıllarda gazeteler aracılığıyla yayımlanmıştır. Nitekim roman 1951 yılına dek ise bağımsız bir kitap olarak yayımlanamamıştır. Ancak romanın gerçek başlangıcı Muhammed el-Munîf'e ait olan ve 1956 y1lında yayımlanan Ve Ahîran Tezevvectuhâ adlı çalışmayla olmuştur. Görüldüğü üzere Tunus'ta roman yazımının başlangıcı ile romanların basımı arasında zamansal farklılık bulunmaktadır. 1951 yılının öncesinde yazılan ilk roman denemelerinin aksine 1951 ile 1969 yılları arasında yazılan on yedi romanın biri dışında hepsi kitap olarak basılmıştır. Diğer modern edebi türlere nispetle roman basım oranının yüksek olması, dergiler ve gazetelerle başlayıp devam eden süreçte bu türün tanınmaya başlaması, kısa öyküye nazaran romanın edebi gazetelere ve dönem dergilerine daha bağlı kalmasına, okur ve yazarlar nezdinde bir yönelişin oluşması gibi nedenlere bağlı olmuştur. Tunus romanı 1980'li yıllara gelindiğinde nicelik bakımından hiç de küçümsenmeyecek bir durumda idi. Nitekim 1985 yılının sonlarında roman sayısı seksene yaklaşırken basılmayan roman sayısı ise 1970 yılı öncesinde yirmi idi. Ayrıca yayım faaliyetlerinin gelişiminin ve üst seviyede yayımcıların ortaya çıkışının da roman türündeki eserlerin basımı hususunda bağımsızlık nesline yardımcı olan hususlardan biri olduğu ifade edilebilir. Bu dönemde aslında yazılmış halde duran metinlerin basılı haldeki metinlerden daha da fazla olduğu düşünülebilir ${ }^{27}$.

\section{Tunus Gazete ve Dergilerinin Edebi Ürünlere Katkıs}


Fransız sömürgeciliği döneminde dilin en canlı kullanıldığı alan gazete yazılarıdır. Aynı zamanda emperyalizme karşı bir silah olarak kullanılan bu fikri içerikli yazılar, sömürge altında yer alan ülkelerdeki nesir türünün gelişmesinde önemli bir paya sahip olmuştur. Bu gazetelerde oluşturulan yeni üslup sayesinde, nesir türü önemli bir ölçüde seciden arındırılmıştır. Söz konusu bu üslupta da özellikle İbn Haldûn'un üslubunun tesiri görülmüştür. Arap Dünyası'nın batısındaki bu edebî uyanış, aslında doğudaki Arap ülkelerinde yaşanan edebî uyanışın bir uzantısıydı. Bu uyanışta özellikle, 1862 yılında Ahmed Faris eş-Şidyâk tarafindan İstanbul'da çıkarılmaya başlanan, daha sonra da Kahire'de devam ettirilen el-Cevâib gazetesinin Osmanlı ülkesi dışında Kuzey Afrika, Hindistan, Güneydoğu Asya Adaları ve Orta Asya gibi İslamiyet'in yaygın olduğu yerlerde geniş bir etkisi olmuştur. Bu nedenle de Kuzey Afrika edebiyatının önde gelen isimleri, Mısır başta olmak üzere doğudaki Araplarla, oralarda yayımlanan gazete ve matbuat yoluyla temas içerisinde olmuşlardır. Kuzey Afrika coğrafyasında millî gazetecilik Tunus'ta 1862 yılında resmî olarak çıkmaya başlayan er-Râidu't-Tûnisî ile başlarken bölge gazeteciliğine mühim katkılar sağlamıştır. "Tunus gazetelerinden erRûznâme et-Tûnisiyye hakkında Muhammed 'Abduh, Bu gazete, medeniyet, ilim ve edebiyatta Arapları güçlendirecek, Tunuslu, konuşan bir ansiklopedidir diyerek takdirini ifade etmiştir. Tunus'ta gazeteler aracıllğıyla ortaya çıkan bu edebi uyanış yeni gelen nesli de etkilemiş, onlarda yeni bir ruhun canlanmasina sebep olmuştur. Bu yeni ruh onlart insan tabiatına yakın olan edebiyata doğru çekmiş ve böylece de hemen hemen dâhî denilebilecek bir grup yazar ve şair ortaya çımıştı. Tunus'ta başlayan bu edebi uyanış daha sonra da Fas ve Cezayir'e de yayıldi" ${ }^{28}$.

XX. yüzyılın başlarında Tunus'ta edebi dergilerin sayısı artış göstermiştir. Ancak pek çoğunun yayımlanmaları bireysel çabalar sayesinde olmuş, ne yazık ki ömürleri de uzun olamamıştır. Örneğin Hayre'd-dîn Dergisi 1906 yılında kurulmuş ve aynı yıl kapanmıştır. es-Sâdlkiyye Dergisi 1920 yılında yayım yaptıktan sonra aynı tarihte de kapanmıştır. el-Fecr ve el-Efkâr dergileri de yayım hayatları bir yıl süren dergiler arasında yerlerini almıştır. Bazı edebi dergilerin bazı özel şahıslarla beraber anılması ise onları daha uzun ömürlü kılmıştır. Örneğin es-Se 'âdetu'l- 'Uzmâ eş-Şeyh el-Hıdır Huseyn tarafından 1904 yılında tesis edilmiş ve iki y1l süresince yayım hayatına devam edebilmiştir. eş-Şeyh Nûreddîn b. Mahmûd, es-Sureyyâ Dergisi'nin ikinci merhalesinde dergiyle ilgilenmiş ve dergi 1934-1950 yılları arasında yayımlanmıştır. Zeynu'l- ‘Ẩbidîn es-Senûsî'nin tesis etmiş olduğu $\mathrm{el}$ - 'Alemu'lEdebî adlı dergi 1930-1935 yılları arasında yayım yapmış ve Mısır'daki Apollo Dergisi'nin eşdeğeri olup Tunus'ta hemen hemen tamamen edebiyata ayrılan ilk derlemeydi. Mahmûd Beyram ise 1936 yılında eş-Şebâb Dergisi'ni tesis etmiştir. Muhammed el-Beşrûş, el-Mebâhis'in 1938 yılında başlayan ilk döneminde idaresini üstlenirken Mahmûd el-Mes'adî ise 1944-1947 yılları 
arasındaki ikinci döneminde dergiyi yönetmiştir. en-Nedve Dergisi Muhammed en-Nifîr tarafindan 1953 senesinde kurulmuş, 1957 yılına dek yayım hayatında kalmış ve el-Fikr Dergisi'nin yerini almıştır. 1930'larda eş-Şebâb gazetesi ve el-Vatan Dergisi'nin sayfalarına bakıldığında sık sık sosyal ve siyasal hicivlerle dolu olduğu ve önemli edebi değerlerin şiirlerinin ve kısa öykülerinin sunulduğu görülecektir. el-Bedr ve el-Fecr adlı dergiler, Mısır'daki el-Muktetaf Dergisi'ne bazı açılardan benzer, edebiyat ve eleştiriyle ilgili konulara yer veren popüler bilimsel ve eğitimsel gazeteciliği ele alan iki süreli yayındı. Aslında bakıldığında bütün bu dergiler peş peşe ortaya çıkmışlardır. Sanki bu dergiler üretilen edebi ürünlerin, eleştirilerin ve yazarların tanıtılması hususunda bir meşale olmuşlardır. Ancak bağımsızlık öncesindeki koşullar nedeniyle yazarlar kısa soluklu çalışmalar yapabilmişlerdir. Bu dönemde yayımlanan gazete ve edebi dergiler, düzensizliklerine rağmen eş-Şâbbî, Sa 'îd Ebû Bekr, Muhammed el-Halyevî ve eş-Şâzelî Haznedâr vs. gibi yazarların doğuşunda önemli rol oynamıştır. Ayrıca bu dönem içerisinde edebiyatın sürdürülmesinde katkısı olan isimlerin arasında, yayıncılık faaliyetleri ve kendi yaratıcı yazılarıyla Zeynu'l-'Âbidîn es-Senûsî, şair Ebu'l-Kâsım eş-Şâbbî (1909-1934), modernist ve sosyal reformcu Tâhir el-Haddâd (d.1935) ve nesir yazarları Mahmûd Beyram el-Tunisî (d.1960) ve 'Ali ed-Du'âcî (1949-) gibi değerli isimler yer almaktadır.

et-Tecdîd Dergisi yeni bir ruhla Fransa'dan dönen üniversiteliler tarafindan kurulmuştur. $\mathrm{Bu}$ dergide hayatı ve düşüncel üretimi tasvir etmişlerdir. Söz konusu dergi 1962 yılına gelindiğinde ise eleştirel fikirlere dayanan ve gelişim fikri gibi sebeplerden ötürü kapanmıştır. İbn Haldûn tarafından çıkartılan Sekâfe Dergisi'nin 1970'li yıllara kadar gayet güzel çalışmaları mevcuttu. Ancak kurucusunun ve editörlerinin değişimi ve düzenli üretimin olmayışı gibi nedenlerle kapanmıştır. İlginç bir durum vardır ki resmî kurumlardan çıkan Şi 'r ve Mesrah gibi edebi dergiler uzun ömürlü olamamaktaydı. 1975 yılında Mahmûd el-Mes'adî kültür bakanı iken tesis ettiği el-Hayatu's-Sekâfiyye adlı derginin maddi ve edebi imkânlarına rağmen kuruluşu geç bir zamana kalmıştır. Eğer imkânlar olsaydı ve düzenli çalışma koşulları da sağlansaydı el-Hayatu'sSekâfiyye adlı derginin kültürlü insanlar arasındaki etkileşim hususunda önemli bir yeri olabilirdi. Bilinen bir gerçek vardır ki o ise Tunuslu pek çok yazarın ve eleştirmenin dergilerde çalıştıklarıdır. Her ayın sonunda okuyucular için hayal kırıklığı olmaması için düzenli bir şekilde çalışmalarını yayımlamak için uğraşmaktaydılar. Dergiler aynı zamanda sınırların ötesinde de yayımlanarak yazarların seslerini duyurmaktaydılar ${ }^{29}$.

Modern Tunus edebiyatında romanların ve kısa öykülerin yayımlanmasında gazeteciliğin önemli bir rolü bulunmaktadır. Öyle ki bağımsızlığın hemen öncesine değin de bu durum böyle süregelmiştir. el- 
Mebâhis Dergisi'nin yayımlanmasının durdurulmasının ardından 1950'li yılların başlarına kadar kısa öykünün yayımlanmasında belirgin bir gerileme meydana gelmiştir. el-Usb $\hat{u}^{\prime}$ gazetesi (1945-1950) bu türdeki çalışmalarıyla tanınan 'Ali ed-Dû'âcî ve Tevfîk Bûğdîr gibi bazı isimleri bir araya getirmeye çalışmış olmasına rağmen yirmi bir kısa öykü ve Zeynu'l-'Âbidin es-Senûsi'ye ait olan ve birkaç fasıldan oluşan bir roman dişında başka bir şey yayımlayamamıştır. Bu önemli gazetenin kısa öykü alanında yayım yoluyla tanınması çoğunlukla 'Ayyâş Mu'arraf'ın yazdığı ürünler sayesindedir.

1955-1986 yılları arasındaki dönem siyasi dönüşümlerin başlangıcına sahne olurken edebi gazeteciliğin etkisi Muhammed Ferec eş-Şâzilî, Muhammed Reşâd el-Hamzâvî ve Reşîd el-Ğalî ve Hasan Nasrr ${ }^{30}$, el-Beşîr Hureyyif ve Mustafa el-Fârisî ${ }^{31}$ gibi yeni öykücülerin ortaya çıkmasıyla birlikte görülür bir biçimde azaldı. Bu nesil 'Ali ed-Dû'âcî, Muhammed el-Beşrûş ve Muhammed el-'Ureybî gibi isimlerle birlikte öykünün içerisinden geçmiş olduğu sosyal eğilimin devamıdır.

el-Fikr Dergisi 1970'li yıllardaki kısa öykü örneklerine dair yüksek oranda çalışmayı kapsaması açısından en güvenilir merci olarak itibar edilir. Ayrıca milli ve edebi davalar hakkında görüşülmesi açısından da saygın bir yerdi. Nitekim bu derginin ilk yıllarından beri sayılarından biri Kadiyyetu'l-Kıssati'tTûnisî olarak isimlendirilen bir çalışmaya tahsis edilmiştir. Bu çalışma o dönemde Fakru'l-Edebi 't-Tûnisî adını taşımıştır.

et-Tecdîd Dergisi öykü yayımlamaya başladığı dönemden itibaren Sâlih elKarmadî, el-Mencî eş-Şemlî, Muhammed Reşâd el-Hamzâvî ve Mustafa elFârisî gibi isimlere ait olan on iki kısa öyküden başka bir şey yayımlamamıştır.

Bağımsızlık sonrası dönemde edebi konularda da uzmanlaşan başka edebi dergiler de ortaya çıkmıştır. eş-Şebâb Dergisi (1956-1970) yaklaşık olarak altmış öykünün yayımlanmasını sağlamıştır. Keza 1970'li yıllardan itibaren gördügüumüz Mahmûd Tarşûne, Rıdvân el-Kevnî, Muhammed Sâlih el-Câbirî, 'Abdulazîz bi'l-Hâc Tayyib ve Muhammed el-Muhtar Cinnât ${ }^{32}$ gibi yeni nesil edebiyatçıların bu dergiye yöneldiklerini görmekteyiz ${ }^{33}$.

1966 y1lında ortaya çıkan el-Kısas Dergisi, kuruluşunun bir buçuk y1l sonrasında Tunus'taki roman ve kısa öykü yazarlarının büyük bir bölümünü bünyesine katmıştı. Bu dergi 1970’li neslin yani ‘'̇zzu’d-dîn el-Medenî, Semir el-'İyâdî ve Rıdvân el-Kevnî, 'Abdulkâdir Bi'l-Hâc Nasr, Mahmûd et-Tûnisî, İbrâhîm b. Murad, Ahmed Memo ve Muhammed el-Hâdî b. Sâlih gibi isimlerin ürünlerine yer vermiştir.

Öykü koleksiyonlarına geldiğimizde ise bu koleksiyonların basımları, bağımsızlığın ilk yıllarında Nâciye Sâmir ve Muhammed Merzûkî gibi isimlerin kitaplarıyla başlamıştır. Yayımlanmış öykü koleksiyonlarının sayısı 1956 ve 1969 yılları arasinda dokuz idi ${ }^{34}$. 
"1900-1962 yılları arasindaki Tunus gazeteleri şu şekildedir: etTekaddum (1906), Murşidu'l-Umm (1906), el-Munîr (1907), elMuşîr (1911), el- 'Asru'l-Cedîd (1920), el-Vezîr (1920), Lisanu'şŞa'b (1920), en-Nahda (1924), el-'Âlemu'l-Edebî (1929), ezZamân (1931), el-Vatan (1936), el-Bûk (1936), ez-Zeytûn (1936), Sabra (1937), Tûnis (1937), el-Mebâhis (1937), el-Usbû'u (1945), el-Amel (1934), es-Sabâh (1950), en-Nedve (1953), el-Fikr (1955), el-İzâ'a (1962) ve el-Luğât (1965) vs". ${ }^{35}$

\section{Tunus Romanında Edebi Ürünler}

Tunus'ta edebi çalışmaların ilk olarak 1905 yılında öykü türüne dair çeşitli denemelerin kaleme alınması, keza yine bu dönemde Fransızcadan hem öykü hem de roman çevirilerinin yapılması, roman türünün de ilk örneklerinin ancak 1930 ve 1940'lı yıllara dayanması ve sanatsal bağlamda ilk romanın ise 1956 yılında yazılması gibi gelişmeleri belirtmiştik.

Tunus romanına dair eserlere yer verdiğimiz bu bölümde şüphesiz ki Tunus romanının en seçkin ismi el-Beşir Hureyyif'tir. Kendisinin roman türünden önce kaleme almış olduğu ilk öyküsü, 1937 yılının Eylül ayında edDustur gazetesinde yayımlanan Leyletu'l-Vatıyye' $\mathrm{dir}^{36}$.

"Genç bir kızın geleneklerin karşısındaki duruşunu gördüğümüz bu eser Tunus halk dilindeydi. Bu nedenle de eleştirmenler nezdinde bir beğeniye nail olamamıştır. Bu yüzden de yazar uzun yillar sessizliğe bürünmüsstür ta ki Iflâs ev Hubbuke Derebâni (1958) adlı romanı çıkıncaya kadar. Bu roman Tunuslu bir gencin aşkının ifadesi olurken söz konusu neslin de deneyimlerini temsil etmekte ve şüpheci bir akl ile hislerin devrimini hafifleten bir dengeye delalet etmektedir. Roman söz konusu gençlerin siyasal sorunlarından ziyade yeniliğin etkisi altında gelişen bir dünyada yaşarken başkentteki küçük bir burjuvaziyi takdim etmektedir. Zira ona göre halkın konuştuğu bu yerel dil, fasih Arapça gibi bir dildir ${ }^{\prime 37}$.

Eserin edebi çevrelerce başarılı görüldüğü ise gerçekten de ortadadır. Bu yüzden de el-Beşîr Hurayyif öykü yazmayı sürdürmüş ve bu öykülerini 1971 yılında Meşmûmu'l-Fell adlı koleksiyonunda bir araya getirmiştir ${ }^{38}$.

Yazarın ikinci romanının olayları ise 1535 yılında İspanyolların ve Türklerin Tunus'a geldikleri zamana rastlamaktadır. Berku'l-Leyl (1961) adını taşıyan bu romanın kahramanı zekâya ve masumiyete sahip, simgesel bir değer taşıyan ve bir halk kahramanı olan zenci köle Berku'l-Leyl'dir. 
el-Beşîr Hurayyif'in bir diğer romanı olan ed-Dıkla fi Aracîniha (1969) diğer romanlara kıyasla uzun oluşuyla bu dönemde şaşırtmıştır. Bu romanın konusu toplumsal trajedilerin kaynağı olan toprak husumeti olup eserdeki olaylar 1919-1930 yıllar1 arasinda Tunus'un güneyinde yer alan Nefta vahasında geçmektedir. Bu romandaki gerçek kahraman ise hurma ağacıdır. Hurma ağacı öncelikle kelimelerdedir. Çünkü aileler arası ilişkiler hurma ağacına bağlıdır. Bu yüzden de planlar iktisadi bakımdan rakipleri düşürmekle başlamaktadır. $\mathrm{Bu}$ şekilde de insan, ahlakın reddettiği fikhi hileleri keşfetmektedir. Kitabın önemine geldiğimizde ise dilsel, coğrafi ve toplumsaldır. Kitaptaki bâblar " "Arcûn", bölümler ise "Şemrûh" olarak adlandırılmıştır ${ }^{39}$.

Reşâd el-Hamzâvî'nin Bûdûde Mâte (1962) ismini taşıan dayanışma içerikli romanı, yazarın sonradan romanlaştırdığı öykülerine dayanmaktadır. Nitekim bu öyküler çoğunluğu yazara ait olan bir öykü koleksiyonunda daha önceden yayımlanmıştır. Bakıldığında öyküler, âdeta çarşıları, kahveleri, otobüs ve meydanlarıyla bir köydeki günlük hayatın renkli ve canlı bir tablosudur. Bu yönü ile eserin genel atmosferi, yazarın diğer öykülerinde hakim olan karamsarlık havası ile çelişmektedir. Romandaki olayların çoğunluğu Mahmut karakteri etrafında dönerken Bûdûde karakteri ise romanı bilmecelerle dolduran ilk semboldür. Mahmut karakteri de Bûdûde sembolünün gölgesinde gelişmektedir. Romanın ilk bölümleri boyunca kenarda kalmış bir karakter olan Mahmut'un sömürgeye karşı direnişine giden yola nasıl gireceği merak konusudur $^{40}$.

Yazarın Tarannino adlı öykü koleksiyonu 1975 yılında yayımlanmıştır. Yazar, burada ülkedeki siyasi gelişmelere dikkat çekerken bu gelişmelerin nasıl şekillendirileceği ve şekil ile içerik bakımından nasıl tepki gördüğünü sorgulamaktadır. Yazarın metinleri âdeta kendi kültürünün yansıttığı 1stırapların bir neticesi ve kimliğinin bir yansımasıydı. Bu nedenle öykülerindeki karakterler hayatla çatışmakta ve hayat istikrarsız bir kırsal ile tehlikeyle parıldayan şehir tecrübesi arasında parçalanmış durumdadır. Öykülerindeki şahsiyetler aşağılık kompleksine sahip karakterlerden oluşmaktadır. Çünkü onlar Arapça dışında bir dil bilmemekte ve ten rengi sebebiyle kırsal kesimdeki kardeşleri için kendilerini feda etmek için hazırlardır. Ama tarif edilemeyen umutlar beslemektedirler. Açıkçası burada edebiyat hayal kırıklığına uğratan bir bekleyişin ardından gizli bir devrime döner. Metinde milli mücadeleye katılan bir grup vardır. Ancak bağımsızlık insanların hallerini değiştirmemektedir ${ }^{41}$.

Modern Tunus romanında tüm türlerde yazılar kaleme alan Muhammed Sâlih el-Câbirî gibi bir isim daha bulunmamaktadır. Risaleye benzeyen Eb 'adu'l-Mesafât (1977) adlı çalışması mevcuttur. Diğer çalışmaları ise eşŞi 'ru't-Tûnisiyyu'l-Mu 'âsır (1974) ve Neş'etu'l-Klssa (el-Kıssatu't-Tûnisiyye- 
Neş'etuhâ ve Ruvvâduhâ) (1975), Dîvânu'ş-Şi 'ri't-Tûnisiyyi'l-Hadîs (Şiir Seçkisi-1976) ve Dirâsât fi'l-Edebi't-Tûnisî (1978) şeklindedir. Kendisi aslında adını Yevm min Eyyâm Zumren (1968) adlı romanıyla duyurmuştur. Müellif, söz konusu romanını tarif ederken insan hayatından bir günü ele aldığını ifade etmiştir. Romanın kahramanı olan Abdullah, mobilya imal eden bir marangozdur. Roman, kapısının küçük bir pazara açıldığı halka açık olan bir yerde başlamaktadır. Yazar, romanda yer vermiş olduğu günlük hayatın detaylarıyla okuyucusunu şaşırtmaktadır ${ }^{42}$. Bu romandaki olaylar Bağımsızlık öncesinde Muncemu'r-Redîf'te meydana gelmektedir. Kahramanla birlikte okuyucu sendika tarafından sağlanan imkânların farkındayken olumlu sonuçlara yol açacak grevlere izin verilmeyişi görmektedir. Bu çalışmada iki durum iç içe geçmiş durumdadır. Birincisi gerçek ile şahıs arasındaki aşamalı olan bir buluşmayı yani treni, köyü, insan unsurunu ve sosyo-ekonomik baskıyı temsil etmektedir. İkincisi ise bireysel endişe hissinden görev bilincine kahramanın içsel sesini temsil etmektedir. Gerçek kahraman mevcut halk olabilir. Yani kendi hakkını isteyenler, firsatları değerlendirenler ve bir köşede kalanlardır. Nitekim bu roman yazarın Keyfe Lâ Uhibbu'n-Nehâr ${ }^{43}$ (1978) adlı tiyatro oyununa benzemektedir. $\mathrm{Bu}$ oyun iki nesil arasındaki fark1 ele almaktadır. Sömürgeye karşı mücadele vaktinin seçimini ilgilendirmesi hususunda ayanlar ve bazı önde gelenler bütünleşirken gençler ise kendi onurlarını korumayı tercih etmişlerdir ${ }^{44}$.

Aslında Tunus kurgusunun en belirgin karakterleri arasında 1975 y1linda Muhammed Sâlih el-Câbirî (d. 1940) tarafından yayımlanan el-Bahr Yenşuru Elvâhahu adlı romandaki Dirbal karakteri yer almaktadır. Dirbal bencildir, ancak kronik olarak tereddütlüdür ve kesin bir karar veremez. Dirbal küçük bir kasabada büyür. On dokuz yaşındayken, aile meclisi onun eğitim için başkente gönderilip gönderilmeyeceğini belirlemek üzere toplanır. Söz konusu roman bağımsızlık sonrası dönüşen bir toplumda geçmektedir. Romandaki karakterlerin hayatları üzerinden aslında üçüncü dünya ülkelerinden birindeki yeni bir tabakanın oluşumunu görebilmek mümkündür. Şehre gelen karakterler aslında şehrin kendilerini manevi değerlerle besleyemediğini görmüşlerdir. Nitekim vatanlarından kendi istekleri ile ayrılmamışlardı. Bu durum karşısında yeniden başlamak için köye dönüş artık kaçınılmaz bir durumdu. Romanda son olarak kadınların geleneksel imajı nasıl terk ettiklerine ve ifade özgürlüğüne değinilmiştir ${ }^{45}$.

Muhammed Sâlih el-Câbirî'nin er-Ruhh Yecûlu fi'r-Rek'a (1977) adlı ikinci öykü koleksiyonuyla sanatsal şekle ulaşabilme imkânı yakalamıştır. Kitabın üçte biri kadınlar ve erkekler arasındaki psikolojik tahlillere dayanmaktadır. İkinci üçte birlik kısım polisiye ve bilim-kurguya dair bir 
düğüm iken son üçte birlik kısım ise sıradan insanların yaşamış oldukları olaylara dayanmaktadır. Bütün metinde ise üslup birliği söz konusudur.

Yazarın Leyletu's-Senevâti'l- 'Aşri (1982)'de modernizmin iki şekilde gelişine şahit olmaktayız. Karakter bir taraftan normal örnekler arasından çıkarken diğer taraftan Kara 26 Ocak 1978 günü yaşanan olaylara bizleri götürmektedir. Kahraman burada idarenin kendisini kovmak istediği bir müdürdür. Çünkü kendisinin çalışanlara pek çok faydası dokunmaktadır. Burada arkadaşlarının kendisi için çıkış yolları aramasını, sendikanın mücadelesindeki iltimasları, idari kâtibinin rolü ve müdürün eşiyle olan ilişkisini net bir şekilde görmekteyiz. İkinci karaktere geldiğimizde ise, eşi dış işlerinde görevli olan ve uzun yıllar Avrupa'da yaşayan bir diplomattır. Eşinin samimiyetine inanmamaktadır. Kahraman, çocuklarını okutmayı düşünürken Tunus'ta kalmaya karar vermiştir. Bu şartlar altında kendisini daha önce tanıyan iş yerinin müdürü ile karşılaşmaktadır. Roman bu psikolojik karşılaşmalardaki bileşenleri geleneksel türdeki üsluplarla tahlil etmektedir. Şüphe yoktur ki Muhammed Sâlih el-Câbirî bu romanıyla sanatında zirveye ulaşmıştır ${ }^{46}$.

Okuyucunun sempatisini kazanan bir diğer Tunuslu roman kahramanı ise Muhammed el-Hadi b. Sâlih'in (1945) kaleme almış olduğu Fî Beyti'l- 'Ankebût 1967 adlı romanındaki Sâlih el-Kadrî karakteridir. Başkahraman Sâlih, meteliksiz bir gençken Almanlara karşı savaşmak için Tunuslularla birlikte Fransızların saflarındayken başındaki saçkırandan dolayı rahatsızlanır. Askerler onu deniz yoluyla birçok farklı limana götürürler. Sâlih el-Kâdri, bu romanda savaştaki cüretkâr maceralarını ve kadınlarla vakit geçirmesine dair mazisini anlatmaktadır. 1972 yılında yayımlanan et-Tehaddî, Muhsin b. Diyâf ${ }^{47} 1 n$ (d.1932) kaleme aldığı bir romandır. Bu çalışmanın Tunus halkının Fransız sömürgeciliğine karşı direnişini anlatan en önemli romanlardan biri olduğunu ifade etmek gerekir ${ }^{48}$.

1980'lerin başlarından bu yana, Tunus edebiyatında roman türü sahip olduğu esnek biçim ve yaratıc1lık gibi özellikler sayesinde yazarlar tarafından tercih edilen bir araç olarak görüldü. Bağımsızlık sonrası hayal kırıklığının yanı sıra, kırsal nüfusun şehre göçü, yaygın olan işsizlik, Avrupa'ya göç ve geleneksel aile yapısının parçalanması ve polis devletinin yükselişi gibi faktörlerin ortaya çıkışı, romanı sanat ve toplum arasındaki bağlantıları en iyi ifade eden edebi bir metne dönüştürmüştür. Nitekim Muhammed Hâdî b. Sâlih Min Hakkihi En Yahlume (1991) adlı romanı gelişmekte olan bir ulustaki entelektüel ve edebi bağlılı̆̆ın problemli rolüyle ilgilenmektedir. Gazeteci, kısa öykü ve roman yazarı olan Muhammed Ridâ el-Kâfi (d.1955)'nin son romanı olan el-Kinâ tahte'l-Cild'te, modern Tunus yazarının sosyal eleştirmen ve üreten sanatçı olarak var olan geleneğini sürdürmektedir ${ }^{49}$.

Tunus romanının sınıflandırılmasına değinmek gerekirse romanların hem nitel hem de nicel artışı nedeniyle, bu durum kaçınılmaz bir hale gelmiştir. 
Tunus romanlarının tasnifi hususunda karşılaşılan en önemli çıkmaz kısa roman yazarlarının tek bir romandan fazla bir şey yazmayarak kısa öykü yazarlarının durumunu yansıtmalarıdır. Ayrıca roman pek çok türe ayrılmıştır ve kullanılan 1stılahlardaki incelikler ne olursa olsun bütün tasnif genelleştirilmiştir. Tunus romanının tasnifi hususunda bazı denemeler yapılmıștır. Bu denemelerin en önemlileri ise Ahmet Memo, Ridvân el-Kevnî ve Mustafa b. el-Keylânî'nin gerçekleştirdiği denemelerdir. Ahmet Memo eserlerdeki incelikleri de baz alarak romanı, psikolojik roman, tarihi roman, mücadeleci roman ve sosyal içerikli roman şeklinde türlerine ayırdı. Bu taksimata eleştirel roman ve tahlili roman vs. gibi başka türler de ilave etmiştir. Söz konusu bu taksimat geniş bir deneme olsa da romanın bütün türlerini kapsamamaktadır. İkinci tasnife geldiğimizde ise, Rıdvân el-Kevnî önceki denemeden istifade etmiş ve bazı 1stılahlar bina etmiştir. Romanı geleneksel ve realist gibi türlere ayırmış, her tür için bir örnek vermiştir. Örnek olarak verilen bu romanların hepsi zikredilen türlere tam anlamıyla uymamaktadır. Nitekim bir roman aynı zamanda diğer türlere dair pek çok özelliği içerebilmektedir. Mustafa b. el-Keylânî'nin gerçekleştirdiği üçüncü tasnife bakıldığında, onun eserleri ayrıntılı bir tasnife tabi tutmadığı görülmektedir. O ele aldığı on iki romana dair derin bir tahlil yaparak üç temel yönelime işaret etmiştir ki bunlar geleneksel roman, gezi romanı ve araştırma romanıdır ${ }^{50}$.

Tunus romanı bağımsızlıktan beri içerik bakımından ulusal eğilim, toplumsal eğilim ve son olarak da zihinsel eğilim gibi muhtelif üç yol izlemiştir. Birincisi yakın geçmişe bakar, geleneksel romanı andırır ve över. İkincisi ise şu anı arar, kendisini geliştirmeye çalışır ve tenkit eder. Üçüncüsü ise gelecekten umutlanır, diğer tüm türlere karşıdır ve alternatif arar.

Ulusal romanda Muhammed el-Arûsî el-Matvî, toplumsal romanda Beşîr el-Hurrayif, zihinsel romanda ise Mahmûd el-Mes'adî öncü konumdadır ${ }^{51}$. Muhammed el-‘Arûs el-Matvî’nin ulusal içerikli roman türünde kaleme almış olduğu romanlar sırasıyla şu şekildedir: Mine'd-Dahayâ (1956), Halîme (1964) ve et-Tût el-Mur. Söz konusu romanların üçü de Fransızlara karş1 ulusal mücadele olaylarından ilham almıştır. Bu romanlar bağımsızlıktan sonra yayımlanmıştır. Tarihi olarak bitmiş bir dönemi nitelerken mücadeleden iktidara giden kişilerin yapmış oldukları şeyleri övmektedir ${ }^{52}$. Halime adlı roman henüz doğmadan babasını kaybeden bir kadının öyküsüdür. Babası bir Fransız sömürgecisine ait olan bir bahçedeki gülü koparmasının ardından kendisine uygulanan cezanın neticesinde hayatını kaybetmiştir. Bu durumun ardından Halîme annesini alıp hemen Tunus'a bu durumu Abdulhamid'e haber vermeye gelir. Sonra da aslında eşinin ulusal direniş hareketinde yer aldığını öğrenir ${ }^{53}$. 
'Abdulhamîd el-Munîf' in "Strru'l-Ma 'reke" (1957), Muhammed Sâlih elCâbirî'nin Yevm min Eyyam Zumren (1968), 'Abdulkâdir Bilhâc Nasır'ın ezZeytûn Lâ Yemût (1969), 'Abdurrahmân 'Ammâr'ın 'İndema Yenhelu'l-Matar (1975) ve Muhammed es-Subhî el-Hâcî'nin es-Sâ'ir (1970) adlı romanları ulusal eğilimin bir yansıması olan eserler çerçevesinde zikretmemiz gereken önemli romanlardandır ${ }^{54}$.

Şüphesiz ki Muhammed el-Muhtâr Cinnât romanlarında olayları yansıtış şekliyle ve ulusal romanın gelişimi hususundaki katkılarıyla ön plana çıkmıştır. Ancak çalışmalarının değeri zamanında bilinmemiş ve 1960'lı yılların sonlarından 1970'li yılların başlarına değin basım için kabul edilmemiştir. Yazar, ele aldığı konuyu ciddiyetle işler. 1970 yılında yayımlanan Urcuvân isimli romanının ilk cildi beş yüz yedi sayfa olup detaylı bir şekilde bilgi verilmiştir. 1972 yılında ise Huyûtu'ş-Şekk adlı ikinci cildi yayımlanmıştır. Üçüncü romanı 1974 yılında yayımlanan ve üç yüz elli beş sayfadan ibaret olan Nevâfizu'z-Zaman adını taşımaktadır. Bu romandaki olaylar 1961 yılının yazı ile aralık ayı arasındaki dönemde geçmektedir. Halkın direnişi sonrasında Fransız askerlerinin Bizerte şehrini tahliyesi söz konusudur. Belki de eserlerinin değerinin bilinmemesi sebebiyle uzun bir sessizlikten sonra kendisi öykü türüne yönelmiş ve el-Ferce fi's-Sukbi (1981) ve Sutûhu'l-Ğasîl (1982) adlı koleksiyonlarını yayımlamıştır. Bazı öyküleri ulusal özelliğini korumuş olsa da yazar olaylara yönelip bazı simgesel ve efsanevi objelere de yer vermiștir. Ulusal nitelikli romanın Muhammed el-Muhtâr Cinnât tarafindan gösterilen çabalar sayesinde şekildeki yenilikler ve yeni konuların ortaya çıkışı nedeniyle 1975 yılına kadar üstlendiği misyonunu tamamladığını görmekteyiz ${ }^{55}$.

Üretim bakımından en fazla toplumsal roman türünde çalışmalar, kaleme alınmıştır. Çünkü bu tür toplumsal gelişmeleri takip etmiş ve eleştirel bir tavırla var olan sorunları tahlil etmiş̧ir. Bu eğilimi el-Beşîr Hurayyif' in ekolü olarak adlandırabiliriz. $\mathrm{Bu}$ dönem öncesinde yazarın en önemli romanlarına baktığımızda şunlar karşımıza çıkmaktadır: Iflâs ev Hubbuke Derebânî ${ }^{56}$ (elFikr-1959), Berku'l-Leyl (el-Fikr-1961) ve ed-Dıkla fi Aracîniha (1969).

Toplumsal roman amacına ulaşmada eleştirel, yapısında tahlilci, olayların gelişiminde geliştirici ve son olarak da karakterlerde, zamanda ve uzamda gerçekçi bir yapıdadır. Bu türün en önemli temsilcileri ise Muhammed Sâlih elCâbirî, Muhammed el-Hâdî b. Sâlih ve 'Umer b. Sâlim ${ }^{57}$, Hasan Nasır, Muhammed el-Bârdî ${ }^{58}$ ve eserlerindeki sanatsal yanının sınırlılığına rağmen Muhiddîn b. Halîfe ${ }^{59}$ gibi isimlerdir. $\mathrm{Bu}$ akımın diğer temsilcilerine geldiğimizde ise sayıları çok olsa da ancak tek bir romanı aşan yazar sayısı çok azdır.

Muhammed Sâlih el-Câbirî, ilk ulusal romanı olan Yevm min Eyyam Zumren (1968)'den sonra şu anı tahlil etmeyi ve bu durumun geçmişi övmekten daha önemli bir eleştiri olduğunu anlamıştır. Tunus toplumunun bütün 
katmanlarını tahlil eden iki romanını yayımlamıştır. Bunlardan birisi el-Bahru Yenşuru Elvâhahu (1975), diğeri ise Leyletu's-Senevâti'l- 'Aşeri' dir Yazar her iki romanda kadınların durumlarına ve şu anki toplumsal dönüşümdeki yerine önem göstermiştir.

Söz konusu bu dönüşümlere Muhammed el-Hâdî b. Sâlih Fi Beyti'l'Ankebût (1976), el-Cesed ve'l-'Asa (1980) ve el-Hareke ve Intikâsu'ş-Şems (1981) adlarındaki üç romanında yer vermiştir. Fi Beyti'l-'Ankebût adlı romanda yazar, toplumsal değerin kesinliğini hissetmemiz için mümkün olan bütün araçları kullanmıştır. Kişi ne kadar çalışırsa çalışsın ve başarı merdivenlerini ne kadar çıkarsa çıksın sahip olduğu sosyal mertebenin düşüklüğünü aşamamakla ortaya çıkan insanın acizliğini ve insanın köklerinin kesinliğini tahlil etmektedir. Muhammed el-Hâdî b. Sâlih bir diğer eseri elCesed ve'l-'Asâ (1980)'da doğrudan okuyucuya seslenmektedir. Öyküde olayların döndüğü bir vakitte ordunun yardımını alarak bir vergi tahsildarı tarafından gerçekleştirilen bir vurguna şahit olunmaktadır. Ancak özgürlüğü olmayan bir üçüncü dünya ülkesinde kültürün rolüne değinilen el-Hareke ve Intikâsu 'ş-Şems (1981) adlı romanda bu durumun farklı bir yönü görülmektedir. Çünkü burada yoksul bir adam olan kahramanın, dayanışmanın genelleşmesi içerisinde devletin kararlarını firsat bilerek zengin olan bir tüccara dönüşmesi ele alınmıştır.

'Umer b. Sâlim, ilk olarak yazılmasından on y1l sonra yayımlanabilen Vâha bilâ Zill (1979) adlı romanı ile ortaya çıkmıştır. Burada bir aşk hikâyesine yer verilmiştir. Kitap olumlu ve olumsuz gelişmelerin ele alındığı küçük fasıllara ayrılmıştır. Bütün hikâye ana karakterin köye varıp köyden çıktığı tam tamına bir senelik zaman zarfında geçmektedir. Ve neden kooperatifçilik başarısız oldu sorusu yöneltilmektedir. Yazar pek çok olumlu etken dile getirmektedir. Üç tutum dikkati çekmektedir. Çalışma imkânları karşısında fakirler sevinmişlerdir. Bazı zenginler partisel disiplinler nedeniyle itaat etmişlerdir. Diğerleri ise tüm imkânlarıyla muhalefet etmişlerdir. Bu olaylar nedeniyle roman kadınların günlük hayatına temas etmektedir. Söz konusu bu romanda yazar, dayanışmaya dair doğrudan bir anlatım benimsemiştir. Da'iretu'l-İhtinâk (1982) adlı eserinde de sendika hareketleri ve 29 Ocak 1978 Olaylarına dair düşüncelerini ifade etmiştir. Bu romandaki Nûra karakteri romanın sonunda bir faciaya maruz kaldıktan sonra bilinmez bir yola girer. Etrafındaki toplumsal alan daralır ve akıl sağlığını kaybeder. Ocak 1978 Olayları meydana gelince Nûra'nın eşi hapse atılır. Bu duruma çok üzülen Nûra eşinin bir gün çıkacağı umuduyla yaşamaktadır ${ }^{60}$.

Ebû Cehli'd-Dehhâs (1984) adlı eserinde ise genel olarak toplumsal durumdan bahsetmiştir. Ancak roman sanatının gelişimi bir metinden diğer metne netliği artırır ve yazar, bu tutumlarıyla kültürlü birisinin kendi toplumunu 
sarsan olaylara karşı salt olumsuz bir seyirci olarak kalmasını reddeder, onun değerlendirme ve yönlendirmede bulunması için 1srarc1 olur ${ }^{61}$.

Kuşkusuz ki bağımsızlık sonrası Tunus öyküsünün en önemli ismi Hasan Nasır olarak görülür. Nasr, aynı zamanda roman türünde Mes'adî ekolünden farklı olarak büyük ufuklar açan önemli bir isimdir ${ }^{62}$. Hasan Nasr' in Dehâlizu 'lLeyl (1977) adlı romanında yazar göç, dayanışma ve turizme dair olan sorunları derin bir şekilde tahlil ederken ikinci romanı olan Hubzu'l-Ard (1985)'ta ise köy hayatına ve bütün zorluklarına rağmen buna s1k1 s1k1 tutunmayı tahlil etmektedir. Söz konusu bu iki romanının yanı sıra yazar Leyâli'l-Matar (1968), 52 Leyle (1979) ve es-Seher ve'l-Cerh (1989) adlı öyküleriyle Tunus'un en önde gelen öykücüleri arasında yerini almıştır ${ }^{63}$.

Çağdaş Tunuslu yazar Hasan Nasr'ın Dâru'l-Bâş̧â adlı romanı Murtaza elŞamih'in çocukluğunu ve kırk yıl sonra Medine'deki veya eski Tunus kentindeki evine geri dönüşünü anlatmaktadır. Annesinden koparıldıktan sonra fiziksel olarak istismara uğradığı ve duygusal olarak dışlandığı babasının evinde büyüdükten sonra Murtaza dünyayı dolaşıp kaygı dolu bir hayat geçirmektedir. Moritanya'da çölde dolaşırken, babasının Sufi arkadaşlarından birinin gizemli bir ziyaretiyle geri dönüşü teşvik edilmektedir. Murtaza, sorunlar yaşayan babasını bulma umuduyla Medine sokaklarındaki adımlarını geriye doğru takip ederek ailesinin evine giderken, çocukluğuna ait görüntüleri, kokuları ve sesleri son derece canlı biçimde tekrar hatırlamakta ve bir yandan da zaman ve mekânda ruhsal bir yolculuğa çıkarak çocukluğu esnasında İslami mistisizme girişini tekrar anımsamaktadır ${ }^{64}$.

Muhammed el-Bârdî Medînetu'ş-Şumûs ed-Dâfi'e (1981) adlı romanında köy ve şehir birbirinden ayrılırken zihinlerde farklılaşmaktadır. Romandaki kahraman olan Reşîd taşraya mensup bir ailede yetişir. Başkent Tunus'ta yer alan Tunus Üniversitesi'nde eğitim alır ve burada yeni bir kültüre tanık olur. Zihninde yer alan eski kültür ile yabancısı olduğu yeni kültüre nasıl adapte olabilecektir? Ya da hayatında üçüncü bir yol bulabilecek midir? Veya bu iki kutuptan da vazgeçmeyecek ya da bunlardan birisini tercih edecektir. Metinde aslında bu sorulara bir anlamda da cevap aranmaktadir ${ }^{65}$. Müellif, hem zikredilen romanında hem de kendisine ait olan el-Mellâh ve's-Sefine (1983) ve Kamhu Ifrikiyye adlı romanlarında hemen hemen aynı sorunları ele almıştır. Bazı geleneklere ve adetlere karşı da eleştirel bir tutum takınmıştır ${ }^{66}$.

Dayanışma problemi, pek çok Tunuslu romancının önem gösterdiği en önemli düşünsel ve toplumsal sorunlardan biri olarak görülmektedir. Bu durum 'Abdurrahmân 'Ubeyd'e ait olan 'Avâsıfu'l-Harîf (1976) adlı eserde net bir şekilde görülmektedir. Sanki bu romanında yazar cinsellik olgusundaki 1srarcılığını dayanışma konusundaki başarısızlığı nedeniyle Tunus toplumunun kaybettiği şeyin yerine koymaktadır ${ }^{67}$. 
Toplumsal romanın bir diğer ismi 'Abdu'l-mecîd 'Atiyye ile Tunus romanı sanatsal romana artık daha da yakındır. el-Munbett (1967) adlı romanda yazar, Tunus'ta deniz kenarında küçük bir şehir olan el-Mehdiye'deki günlük hayata işaret etmektedir. Geleneklerin ortasında evliliği ve çevreyi, aynı zamanda yeniliğin etkisindeki toplumsal ilişkileri içeriden gözlemleyebilmiştir. Romandaki asıl soruna geldiğimizde ise $\mathrm{o}$, eğitimini sürdürmek isteyen, hırsları olan sıradan bir memurun terfisidir. Ancak o, idarenin kendisini anlamadığını ve bu nedenle de onunla tartıştığını ifade etmektedir. Bunun üzerine de görevini bırakıp üniversite eğitimi için Fransa'ya gitmiştir. 'Abdu'l-Mecîd 'Atiyye on yıl sonra Hattuke Redî' (1978) adını taşıyan ikinci romanını yazmıştır. Burada evlerde ve iş yerlerinde telefon kullanımının önemine işaret ederken, idare ve memurlar arasındaki haftanın beş iş gününe sıkıştırılmış ilişkilerle de ilgilenmektedir ${ }^{68}$.

Günümüzde ve geçmişte Tunus sahilindeki günlük hayata dair kesitleri dikkatli bir şekilde ele alan Muhiddîn $b$. Halîfe'de kaydetme eğilimi daha fazla görülmektedir. Bu nedenle söz konusu yazarın Eşbâhu's-Sûk (1979) gibi romanlarının sayfa sayısı yedi yüzü bulmuştur. Eşbâhu's-Sûk, çarşı hayatından pek çok kare ile dolup taşmaktadır. Kuşkusuz ki sokak ve dükkanların cephesi olayların geçtiği yerlerdir. Burada ulusal hareketi övmek isteyen birinin siyasi bir tutumu yüklenerek günlük hayata ilişkin hassas bir niteleme görülür. Müellif, eş-Şecera adlı romanını 1972 yılında, er-Remâd adlı romanını ise 1975 yılında yayımlamıştır. Bir sonraki sene ise Sûku'l-Kilâb (1979) adlı üçüncü romanını kaleme almıştır. Ancak üst üste eserlerin kaleme alınması üslup düşüklügüne ve düşüncelerin derinleşmemesine neden olmaktadır ${ }^{69}$.

'Abdu'l-mecîd 'Atiyye, bahsi geçen el-Munbett ve Hattuke Redî' adlı iki romanında Tunus yönetiminin ilerleme noktasında önündeki engel olarak gösterdiği pasiflik ve stabil kalma gibi sorunlara odaklanmıştır. Söz konusu bu iki durum müellifin başından geçen olaylar olduğu gibi aynı zamanda sonuçları nedeniyle sıkıntı da çekmiştir. Tunuslu yazarların pek çoğunun ele aldığı bu olgu, yazarların kendi hayat hikâyelerine dair unsurlara odaklanmaktadır. Nitekim Muhammed el-Habîb İbrâhîm'e ait olan Ene ve Hiye ve'l-Ard (1978) adlı romanında bazı öğrencilerin ve öğretmenlerin meşguliyetleri tasvir edilmiştir. Muhammed el-'Âbid Mezâlî'nin 'Alâ Markasi'l-Eşbâh adlı romanı ez-Zâyîr'de elçilik yaptığı sıralarda yabancı insanları ele aldığı bir öyküsüdür. 'Abdulkâdir bi'l-Hâc Nasr, Sâhibetu'l-Celâle (1983) adlı romanında, Tunus Radyosu'ndayken şahit olduğu oyunları ve şüpheli ilişkileri aktarmıştır. Zekiye 'Abdulkâdir'e ait olan Âmine (1983) adlı çalışmada yazar, kendisine iyi davranmayan Cezayirli bir doktorla kişisel hikâyesini kaydetmektedir. Gazeteci Cemâleddîn Bûrîka Nesîcu'l- 'Ankebût adlı romanında gazeteciliğin ortamından bahsetmektedir. Muhammed Sa'îd el-Kattârî, Gaybûbetu'l-Ard (1983), 
İbrâhîm el-‘Ubeydî Kissatu'l-Hûha (1980) ve İsmâ‘îl Bûsruvâl, Kullunâ Fî Vechi'l-'Âsıfe (1985) adlı eserlerinde kendi yaşamlarından kesitlere yer vermişlerdir ${ }^{70}$.

Toplumsal romanın mümessilleri arasında yer alan 'Abdu'l-Mecîd 'Atiyye, Muhiddîn b. Halîfe, Hasan Nasr Muhammed el-Bârdî, Muhsin b. Diyâf, Muhammed el-Hâdî b. Sâlih ve 'Umer b. Sâlim vs. gibi yazarların Tunus'taki roman hareketinin gelişimi hususunda önemli yerleri bulunmaktadır. $\mathrm{Bu}$ yazarlar, siyasal sorunları inceleme, sendikacılık, bazı toplumsal gruplar arasındaki çatışmaların tasviri, göç problemlerinin tahlili, kültürlü kişilerin tahlili ve onların toplum içerisindeki yerleri ve iktidarla ilişkileri, modern kadının statüsü ve çiftçilerin sorunları gibi konulara değinmeyi elzem görmüşlerdir. Bu tür içerisinde Mustafa el-Fârisî’nin elMun 'aric (1966), ‘Abdulkâdir Bi'ş-Şeyh'in Ve Nasîbî mine'l-Ufuk (1970) gibi romanları susuzluk ve suyu aramaya dair yollara farklı üsluplarla yer vermişlerdir ${ }^{71}$. el-Mun 'aric adlı romanın başlangıcında Adil karakteri yazılar yazmaya çalışan ve değişikliğe inanan aydın birisidir. Roman yavaş yavaş medeni ve siyasal bir iltizamdan varlığın tereddünün olduğu bir alana kayar. Söz konusu bu şaşkınlık yaşının baharında adili seven Cîcî isimli Fransız bir kadın ile Tunus' ta mühendis olarak çalıştığı esnada onunla tanıştığı Selvâ isimli bir kadın arasındaki tereddüttür ${ }^{72}$.

Tunus'ta bir komisyon tarafindan telif edilen Tarihu'l-Edebi't-Tunisî: elHadîs ve'l-Mu'âsır (Beytu'l-Hikme, 1993) adlı eserde konumuzla ilgili şu bilgiler verilmiştir:

"el-Beşîr Hurayyif'in toplumsal roman alanında tohumların
ektiği şeyler kısa sürede meyvelerini vermiştir. Yapılan
çalışmalara bakıldığında bunlardan bazılarının yazarın
kendisinin yaptı̆̆ çalışmalara yakı olduğu görülürken
bazılarının da kendi çalışmalarının gelisstirilmiş hali olduğu
anlaşlmıştır. Ancak bu eserlerin sahipleri her şeyden önce
romanın bir sanat olduğunu anlamamışlardır. Verilmek istenen
mesaj gerek fikri gerekse reformist olup sanatsal bağlamda fayda
sağlamıyorsa hedefine ulaşamaz"73.

Zihinsel romana geldiğimizde ise kendine has amaçları ve bir üslubu bulunmaktadır. Diğer tarzlardan doğmamıştır. Ancak telif bakımından diğer tarzlardan daha da eski olabilir. Zihinsel roman çerçevesinde değerlendirilebilecek ilk örnekleri 1930'lu yılların sonlarından 1940'lı yılların başlarına kadarki dönemde görmekteyiz. Bu eğilimde Mahmûd el-Mes‘adî’nin metinlerine öncelik vermemiz gerekmektedir. Kendisi bu türün kurucusudur. Zihinde, düşünceler ve değerler arasında bir mücadele oluşturmuştur. Aslında nisbi olarak bir mekân belli olsa bile zaman belirli değildir. Çünkü onun amaçları, durumu ve mekânı aşıp insanın cevherine varmaktan geçmektedir. 
İnsanın varlığı, yoklukla olan ilişkisi, sonsuzluğu arzulaması ve yaratması gibi değerler zihinsel romanın amaçları - unsurları - arasındadır. Örneğin karakter karşınızda canlanır, konuşur ve sanki siz onları canlı yaratık olduklarını düşünürsünüz, aslında onlar insan suretindeki düşüncelerden başka bir şey değillerdir.

Zihinsel roman birleştirilmiş bir suret değildir. Bütün romanlarda ona dair unsurlara rastlanmaz. Çünkü bu türün kuruluşu ve devamı arasındaki zamansal süreç yirmi beş yıl gibi bir süredir. Bu türün örneklerine bakacak olursak Ferec el-Havâr, Selahaddîn Bûcâh ve Hişâm el-Karavî gibi isimler 1980'li yıllardan itibaren bu akım çerçevesinde yazılarını kaleme almaktadırlar ${ }^{74}$.

\section{Sonuç}

Modern Tunus edebiyatına bakıldığında diğer Arap ülkelerinden geri kaldığ1 görülürken bu durumun ardında yatan nedenin hem Fransız işgali hem de Arap ülkelerinde meydana gelen çeşitli olaylar olduğunu ifade etmemiz yerinde olacaktır. Ancak Fransızlar tarafından uygulanan baskıya rağmen edebi sahada ciddi şekilde ilerlemeler kaydedildiği görülmektedir. Ayrıca Tunus'ta meydana gelen edebi çalışmaların 1901 yılı gibi erken bir tarihte oluşması ise diğer Arap ülkelerine nazaran dikkat çekici bir başka durumdur. Söz konusu bu çalışmalarda muhtelif pek çok konunun işlendiği görülür. Tunus romanın başlangıcı ise 1930'lu yılların sonlarına dayanırken sanatsal bağlamda romanın yazılışı ise 1950'li yıllara tekabül etmektedir. Bu arada bu türde ön plana çıkan en önemli ismi el-Beşîr Hurayyif'i zikretmek gerekmektedir. Modern Tunus edebiyatı, Tunus'un Fransız işgalinden 1956 yılında kurtulmasının ardından edebi bağlamda ciddi bir gelişme kaydetmiştir. Özellikle bağımsızlık öncesinde yapılan çalışmaların bir sonucu olarak genel bağlamda edebiyat özelde ise roman türü sanatsal bir ivme yakalayabilmiştir. Hem bunun etkisi hem de edebi ürünlerin basımında yaşanan gelişmeler okur sayısının artışını ve de edebiyatı olumlu bir şekilde etkilemiştir. Bağımsızlık sonrasında özellikle 1980'li yıllarda ise Tunus edebiyatında roman türü sahip olduğu esneklik, yaratıcılık ve ifade etme tarzı nedeniyle tercih edilen bir araç vazifesi görmüştür. Bu yüzden de birbirinden farklı pek çok tema bu tür üzerinden işlenmiş ve roman türünün ulusal, toplumsal ve zihinsel roman gibi türlere ayrılması elzem bir hale gelmiştir. Bu türlere göre yazarlar tarafından çeşitli yazılar kaleme alınırken aynı zamanda Tunus toplumunda yaşanan sorunlar başta olmak üzere pek çok muhtelif tema çalışmalarda işlenmiş ve yeri geldiğinde de eleştirel bir tavır takınılmıştır. 


\section{Kaynakça}

Boullata, I.J., "Çağdaş Arap Yazarlar ve Edebi Miras”, Çev. Eyyüp Tanriverdi, International Journal of Middle East Studies, C.XV, no: 1 (Şubat 19B3).

Câbirî, M.S., (1991) el-Edebu'l-Cezairî fì Tunis: 1962-1990, C.I, elMuessesetu'l-Vataniyye li'l-Terceme ve't-Tahkîk ve'd-Dirasât (Beytu'l-Hikme), Tunus.

Fontaine, J., Slama, M. B. H., (1992) "Arabic-Language Tunisian Literature (1956-1990)", Research in African Literatures, Vol. 23, No. 2, North African Literature (Summer).

Fountaine, J. (1989) el-Edebu't-Tûnisiyyi'l-Mu'âsır, Tunus, ed-Dâru'tTûnisiyye.

Granara, W. (2003) "Tunisia", Encyclopedia of African Literature, Editor: Simon Gikandi, New York, Routledge.

Hâc, b. 'A, (2010) “Temezzehuratu'l-Âhar fî’r-Rivâyeti'l-'Arabiyyeti'lMeğâribiyye”, Vahran Üniversitesi, Edebiyat Dil ve Sanat Fakültesi Yayımlanmamış Yüksek Lisans Tezi, Vahran.

Kaysûme, M. (2012) el-Edebu'l-Hamîm fín'n-Nesri'l- 'Arabî'l-Hadîs, Tunus, Dâru'- Tûnisiyye li'l- Kuttâb.

Komisyon, (1993) Tarihu'l-Edebi't-Tunisî: el-Hadîs ve'l-Mu 'âsır, Beytu'l-Hikme: el-Muessesetu'l- Vataniyye li't-Terceme ve'tTahkîk.

Mefkûde, S., Ebhâs fî̀'r-Rivâyeti'l- 'Arabiyye, Menşûrât Mahber Ebhâs fî'l-Luğati ve'l-Edebi'l-Cezâirî, Biskra, t.y.Ostle, R.C., "Mahmûd el-Mas'adî and Tunisian's 'Lost Generations' ", Journal of Arabic Literature, 8, 1977.

Parıldı, M. (2010) “Fransız Sömürgeciliği Döneminde Kuzey Afrika'da Arap Dili ve Edebiyatına Genel Bir Bakış", Bilimname, Sayı: XVIII.

Perkins, K. (2014) A History of Modern Tunisia, New York, Cambridge University.

Sakkut, H., (2000) The Arabic Novel (Bibliography and Critical Introduction 1865-1995), C.1, New York, The American University in Cairo Press. 
Tarşûne, M. (2002) Min A 'lâmi'r-Rivâye fî Tunis, Merkezi'n-Neşri'lCami'î.

Yazıc1, H. (2002) “Tunus’ta Modern Arap Edebiyatı ve Ebu'l-Kâsım eşŞâbbî”, Nüsha Dergisi, sayı: 5. s. 51-69.

Zâvî, L. "Min Kadâya'l-İbdâ‘i'r-Rivâî Kırâe fî̀ Tecribeti'l-Beşîr Hureyyif er-Rivâiyye", Muntede 'l-Ustâz Dergisi, Cilt 5, Sayı 1.

(Çevrimiçi)https://books.google.com.tr/books/about/Return_to_Dar_Al _Basha.html?id=LK4PAAAAYAAJ\&redir_esc=y 21.09.2019.

(Çevrimiçi) https://meemmagazine.net/2018/10/02/الكاتب_الكبير -حسن. 21.09.2019 /نصر -في-بيت_الرو اية_اليل.

${ }^{1}$ Jean Fontaine ve Mounir B. H. Slama, Arabic-Language Tunisian Literature (19561990), Research in African Literatures, Vol. 23, No. 2, North African Literature (Summer, 1992), s.183.

${ }^{2}$ Fontaine ve Slama, a.g.e., s.183.

${ }^{3}$ Hüseyin Yazıc1, "Tunus'ta Modern Arap Edebiyatı ve Ebu'l-Kâsım eş-Şâbbî”, Nüsha Dergisi, say1: 5, 2002, s. 52.

${ }^{4}$ Müellif, 10 Nisan 1917 tarihinde Tunus'un güneyinde yer alan Nefta'da dünyaya gelmiştir. 1983 yılında vefat etmiş̧ir. Yazar ve eserleri hakkında daha ayrıntılı bilgi için bkz. Mustafa b. el-Keylânî, Tarihu'l-Edebi't-Tûnisî: el-Edebu'l-Hadîs ve'l-Mu'âsır: er-Rivâye, el-Muessesetu'l-Vataniyye li't-Terceme ve't-Tahkîk ve'd-Dirâsât, Beytu'l-Hikme, Tunus, 1990, s. 58.

5 Mahmûd el-Mes'adî, 28 Ocak 1911 tarihinde Tunus'un güneyinde yer alan Tazerka'da dünyaya gelmiştir. 1936 yllında bir Fransız Üniversitesi'nde Arap dili ve edebiyatı bölümünü bitirerek diploma almaya hak kazanmıştır. 1947 senesinde Sorbon Üniversitesi'nde master eğitimini tamamlamıştır. 1980'li yıllarda çeşitli siyasi ve sendikaya dair önemli işler üstlendi. Çalışmaları şu şekildedir: Haddese Ebû Hureyre Kâle, es-Sudd, Mevlidu'n-Nisyân (Unutkanlığın Doğuşu), Te 'sîlen li'Kiyân. Yazar ve Eserleri hakkında daha ayrıntılı bilgi için bkz.: Mustafa b. elKîlânî, Tarihu'l-Edebi't-Tûnisî : el-Edebu'l-Hadîs ve'l-Mu'âsır: er-Rivâye, elMuessesetu'l-Vataniyye li't-Terceme ve't-Tahkik ve'd-Dirâsât, Beytu'l-Hikme, Tunus, 1990, s. 12.

${ }^{6}$ Müellif, 6 Ocak 1906 tarihinde Munastır'da dünyaya gelmiştir. Eserleri: 'Alâ Merkasi'l-Eşbâh, Muhasebe ilmine dair olan bir kitabın tahkiki, el-Fikru'l- 'Arabî fi Muftereki's-Subuli (Fransızca). İlgili romanın karakterlerine bakıldığında gerçekten ilham alınıp yazıya aktarıldığı görülmektedir. Yazar ve eserleri hakkında daha ayrıntılı bilgi için bkz. el-Kîlânî, a.g.e., s. 147.

${ }^{7}$ Yazic1, a.g.e., s. 52-53. 
8 Söz konusu kitabın adı kimi kaynaklarda Ehâdîs Ebû Hureyre Kâle şeklinde geçmektedir.

${ }^{9}$ Sâlih Mefkûde, Ebhâs fì'r-Rivâyeti'l- 'Arabiyye, Menşûrât Mahber Ebhâs fî'l-Luğati ve'l-Edebi'l-Cezâirî, Biskra, t.y, s. 13.

10 Ayrıntılı bilgi için bkz.: el-Kîlânî, a.g.e., s. 12.

${ }^{11}$ Sâlih Mefkûde, Ebhâs fî̀'r-Rivâyeti'l- 'Arabiyye, Menşûrâ Mihberi Ebhâs fî'l-Luğati ve'l-Edebi'l-Cezâirî, Biskra, t.y, s. 13.

12 el-Hâc b. 'Ali, “Temezzehurâtu'l-Âhar fî'r-Rivâyeti'l-'Arabiyyeti'l-Meğâribiyye”, Vahran Üniversitesi, Edebiyat Dil ve Sanat Fakültesi Yayımlanmamış Yüksek Lisans Tezi, Vahran, 2010, s. 10.

${ }^{13}$ Hamdi Sakkut, The Arabic Novel (Bibliography and Critical Introduction 1865 1995), C.1, The American University in Cairo Press, New York, 2000, s. 134-135.

${ }^{14}$ Sakkut, a.g.e., c.1, s.135-136.

${ }^{15}$ Issa J. Boullata, "Çağdaş Arap Yazarlar ve Edebi Miras”, Çev. Eyyüp Tanrıverdi, International Journal of Middle East Studies, C.XV, no: 1 (Şubat 19B3), s. 105.

${ }^{16}$ R.C.Ostle, "Mahmûd el-Mes'adî and Tunisian's 'Lost Generations' ", Journal of Arabic Literature, 8, 1977, s.162.

${ }^{17}$ Sakkut, a.g.e., C.1, s.135-136.

${ }^{18}$ Müellif, 14 Ekim 1931 tarihinde Tunus'un batısında yer alan Bârdû şehrinde dünyaya gelmiştir. Arap dili ve edebiyatı mezunudur. el-Fikr Dergisi'nin editörlüğünü yürütmüştür. Kültür Bakanlığı'nda proje başkanlığı yapmıştır. Yazar ve eserleri hakkında daha ayrıntılı bilgi için bkz.: el-Kîlânî, a.g.e., s. 192.

${ }^{19}$ Müellif, 1920 yılında el-Matviyye'de dünyaya gelmiştir. Müellif, şiir öykü ve roman türlerinde eserler kaleme almıştır. Ayrıca düşünce ve felsefeye dair de çeşitli çalışmaları bulunmaktadır. Tunuslu Yazarlar Birliği’nin başkanlığının yanı sıra Nâdi'l-Kıssa adlı derginin de müdürlüğünü yürütmüştür. Çalışmaları: Ferha Şa 'ab, Mine'd-Dehlîz (Şiir Divanı); Halîme. et-Tûtu'l-Mur (Roman). Yazar ve eserleri hakkında daha ayrıntılı bilgi için bkz.: el-Kîlânî, a.g.e., s. 25.

${ }^{20}$ Sakkut, a.g.e., C.1, s. 135-136; el-Kîlânî, a.g.e., s. 192.

${ }^{21}$ Komisyon, Tarihu'l-Edebi't-Tunisî : el-Hadîs ve'l-Mu'âsır, Beytu'l-Hikme :elMuessesetu'l-Vataniyye li't-Terceme ve't-Tahkîk, 1993, s. 33-34.

${ }^{22}$ Komisyon, a.g.e., s. 33-34.

23 el-Kîlânî, a.g.e., s. 9.

${ }^{24} 1934$ yılında Tâle kasabasında dünyaya gelmiştir. Arap dili ve edebiyatı sahasında doktora yapmıştır. Tunus Üniversitesi'nde görev yapmaktadır. Öykü ve roman yazarıdır. Bûdûde Mâte (Roman), Tarannino (Öykü Koleksiyonu), Arapça sözlük gibi çalışmaları mevcuttur. Yazar ve eserleri için bkz.: el-Kîlânî, a.g.e., s. 25.

${ }^{25}$ Müellif, 9 Ocak 1940 tarihinde dünyaya gelmiştir. Tunus, Bağdat ve Cezayir'de eğitim almıştır. Arap edebiyatı sahasında doktora yapmıştır. Roman ve kısa öykü gibi türlerde eserler vermiştir. Yazar ve eserleri hakkında daha ayrıntılı bilgi için bkz.: el-Kîlânî, a.g.e., s. 108.

26 Komisyon, a.g.e., s. 65,70; Kenneth Perkins, A History of Modern Tunisia, Cambridge University, New York, 2014, s. 185.

${ }^{27}$ Komisyon, a.g.e., s. 65,137.

${ }^{28}$ Metin Parıldı, "Fransız Sömürgeciliği Döneminde Kuzey Afrika'da Arap Dili ve Edebiyatına Genel Bir Bakış", Bilimname, Sayı: XVIII, 2010/1, s. 120-121. 
${ }^{29}$ Mahmûd Tarşûne, Min A 'lâmi'r-Rivâye fî Tunis, Merkezi'n-Neşri'l-Cami‘̂̂, 2002, s. 42-44; R.C.Ostle, "Mahmûd el-Mas'adî and Tunisian's 'Lost Generations' ", Journal of Arabic Literature, 8, 1977, s. 153-154.

${ }^{30}$ Müellif, 1937 yılında dünyaya gelmiştir. Arap dili ve edebiyatı diploması elde etmiştir. Liselerde hoca olarak ders vermiştir. Öykü ve roman türlerinde eserler kaleme almıştır. Aslında bağımsızlık sonrası Tunus'un en önemli öykücülerinden birisidir. Dehâlîzu'l-Leyl adlı bir romanı bulunmaktadır. el-Kîlânî, a.g.e., s. 143.

${ }^{31}$ Müellif, 26 Aralık 1931 tarihinde Safâkis’te dünyaya gelmiş ve burada büyümüştür. 1954 yılında Arap dili ve edebiyatı diploması almıştır. Ulusal kurumların başında pek çok önemli sorumluluklar üstlenmiştir. Tunuslu Yazarlar Birliği üyesidi. elAhyâr ve et-Tûfân tiyatro oyunları kaleme almıştır. el-Mun 'aric, el-Kantara Hiye el-Hayât, Harekât, el-Fitne ve Seraktu'l-Kamer isimlerini taşıyan roman ve öyküler telif etmiştir. Yazar ve eserleri hakkında daha ayrıntılı bilgi için bkz.: elKîlânî, a.g.e., s. 39.

${ }^{32}$ Müellif, 13 Nisan 1930 tarihinde Kafsa'da dünyaya gelmiştir. Eğitim alanıyla meşgul olmuştur. Makale, kısa öykü, roman, çocuk öyküleri ve eleştiri yazıları kaleme almıştır. Yazar ve eserleri hakkında daha ayrıntılı bilgi için bkz. el-Kîlânî, a.g.e., s. 87.

${ }^{33}$ Komisyon, a.g.e., s. 62-64.

${ }^{34}$ Komisyon, a.g.e., s. 64-65.

35 Muhammed Sâlih Câbirî, el-Edebu'l-Cezairî fî Tunis: 1962-1990, C.I, elMuessesetu'l-Vataniyye li'l-Terceme ve't-Tahkîk ve'd-Dirasât (Beytu'l-Hikme), Tunus, 1991, s. 16.

${ }^{36}$ Jean Fountaine, el-Edebu't-Tûnisiyyi'l-Mu 'âsır, ed-Dâru't-Tûnisiyye, 1989, Tunus, s. 65.

37 Jean Fountaine, el-Edebu't-Tûnisiyyi'l-Mu 'âsır, ed-Dâru't-Tûnisiyye, Tunus, 1989, s. 65-66; La'amûrî Zâvî, "Min Kadâya'l-İbdâ'i'r-Rivâ'î Kırâ'e fî̀ Tecribeti'l-Beşîr Hureyyif er-Rivâ'iyye", Muntede'l-Ustâz Dergisi, Cilt 5, Sayı 1, s. 318.

${ }^{38}$ Jean Fountaine, el-Edebu't-Tûnisiyyi'l-Mu'âsır, s. 65.

${ }^{39}$ Fontaine, el-Edebu't-Tûnisiyyi'l-Mu'âsır, s. 65-66.

${ }^{40}$ Jean Fountaine, el-Edebu't-Tûnisiyyi'l-Mu 'âsır, s. 67-68.

${ }^{41}$ Fontaine, el-Edebu't-Tûnisiyyi'l-Mu 'âsır, s. 67-68; Yazar ve eserleri hakkında daha ayrıntılı bilgi için bkz.: el-Kîlânî, a.g.e., s. 25.

42 el-Kîlânî, a.g.e., s. 136.

43 İlgili tiyatro oyunu hakkında detaylı bilgi için bkz.: el-Fikr gazetesi , Sayı: 9, 1. Haziran 1967, Tunus.

${ }^{44}$ Fontaine, el-Edebu't-Tûnisiyyi'l-Mu'âsır, s. 70-72.

${ }^{45}$ Sakkut, a.g.e., C.1, s. 137.

${ }^{46}$ Fontaine, el-Edebu't-Tûnisiyyi'l-Mu'âsır, s. 70-72.

${ }^{47}$ Müellif, 19 Ocak 1932 tarihinde Tunus’ta dünyaya gelmiştir. Carnot Enstitüsünde eğitim almıştır. Zeytûne Üniversitesi ve 'Ayn Şems Üniversitesi Edebiyat Fakültesi'nde 1963 yılında diploma almıştır. et-Teheddî (Roman), Yevm Mine'l'Umr (Roman); Kelimât 'Alâ Cidâri's-Samt (Öykü Koleksiyonu), Yevm Mine'l'Umr (Roman). Yazar ve eserleri hakkında daha ayrıntılı bilgi için bkz.: el-Kîlânî, a.g.e., s. 136.

NÜSHA, 2019; (49): 69-96 
${ }^{48}$ Sakkut, a.g.e., c.1, s. 138; Fontaine, el-Edebu't-Tûnisiyyi'l-Mu'âsır, s. 70-72.

4949 William Granara, "Tunisia", Encyclopedia of African Literature, Editor: Simon Gikandi, Routledge, New York, 2003. s. 529.

${ }^{50}$ Komisyon, a.g.e., s. 137-138.

51 Tarşune, a.g.e., s. 66.

52 Komisyon, a.g.e., s. 138-139.

${ }^{53}$ Yazar ve eser hakkında daha ayrıntılı bilgi için bkz.: el-Kîlânî, a.g.e., s. 28.

54 Tarşune, a.g.e., s. 66.

${ }^{55}$ Komisyon, a.g.e., s. 139-140; el-Kîlânî, a.g.e., s. 87.

${ }^{56} 1980$ yılında kitap olarak basılmıştır. Bkz. Şerîf Bumûsâ ‘Abdulkâdir, el-Fihrisu'lBîblîyûgrâfî li'r-Rivâyeti't-Tûnisiyye ve'l-Lîbiyye ve'l-Mûrîtâniyye (1906-2015), C. 3, Londra, E-Kutub Ltd., 2018, s. 19.

${ }^{57}$ Müellif, 1932 yılında el-Mutavviye'de dünyaya geldi. Sirasıyla Zeytûne, el-Kâhire ve Lübnan Üniversitelerinden mezun oldu. Paris Üniversitesi'nde Arap gramerine ilişkin doktora yaptı. Yazar ve eserleri hakkında daha ayrıntılı bilgi için bkz.: elKîlânî, a.g.e., s. 180.

${ }^{58}$ Müellif, 1947 yılında Kabse şehrinde dünyaya gelmiştir. Arap edebiyatı mezunu olup bu alanda doktora yapmıştır. Safâkis Üniversitesi'nde dersler vermektedir. Öykü, roman ve edebi makale gibi türlerde yazılar kaleme almaktadır. Yazar ve eserleri hakkında daha ayrıntılı bilgi için bkz.: el-Kîlânî, a.g.e., s. 163.

59 Müellif, 1938 yılında dünyaya gelmiştir. Öğretmenlik yapmıştır. eş-Şecera, erRemâd, Eşbâhu's-Sûk adlı eserleri bulunmaktadır. Yazar ve eserleri hakkında daha ayrıntılı bilgi için bkz.: el-Kîlânî, a.g.e., s. 154.

${ }^{60}$ el-Kîlânî, a.g.e., s. 180.

${ }^{61}$ Komisyon, a.g.e., s. 142-144.

62 الكاتب_الكبير -حسن-نصر -في-بيت-/Çevrimiçi) https://meemmagazine.net/2018/10/02/ 21.09.2019.

${ }^{63}$ Komisyon, a.g.e., s.144-146; Mansûr Kaysûme, el-Edebu'l-Hamîm fì'n-Nesri'l'Arabî'l-Hadîs, Dâru'-Tûnisiyye li'l-Kuttâb, Tunus, 2012, s. 104.

${ }^{64}$ (Çevrimiçi)https://books.google.com.tr/books/about/Return_to_Dar_Al_Basha.html? $\mathrm{id}=$ LK4PAAAAYAAJ\&redir_esc $=\mathrm{y}$ 21.09.2019.

65 el-Kîlânî, a.g.e., s. 163.

${ }^{66}$ Komisyon, a.g.e., s. 145.

${ }^{67}$ Komisyon, a.g.e., s. 146.

${ }^{68}$ Fontaine, el-Edebu't-Tûnisiyyi'l-Mu 'âsır, s. 69-70.

${ }^{69}$ Komisyon, a.g.e., s. 145; el-Kîlânî, a.g.e., s. 154.

${ }^{70}$ Komisyon, a.g.e., s. 146-147.

${ }^{71}$ Tarşune, a.g.e., s. 67-68.

72 el-Kîlânî, a.g.e., s. 39.

${ }^{73}$ Komisyon, a.g.e., s. 147.

${ }^{74}$ Tarşune, a.g.e., s. 68-69. 